\title{
COOPER-HENITT MUSEUM
}

\section{COLUMNS}





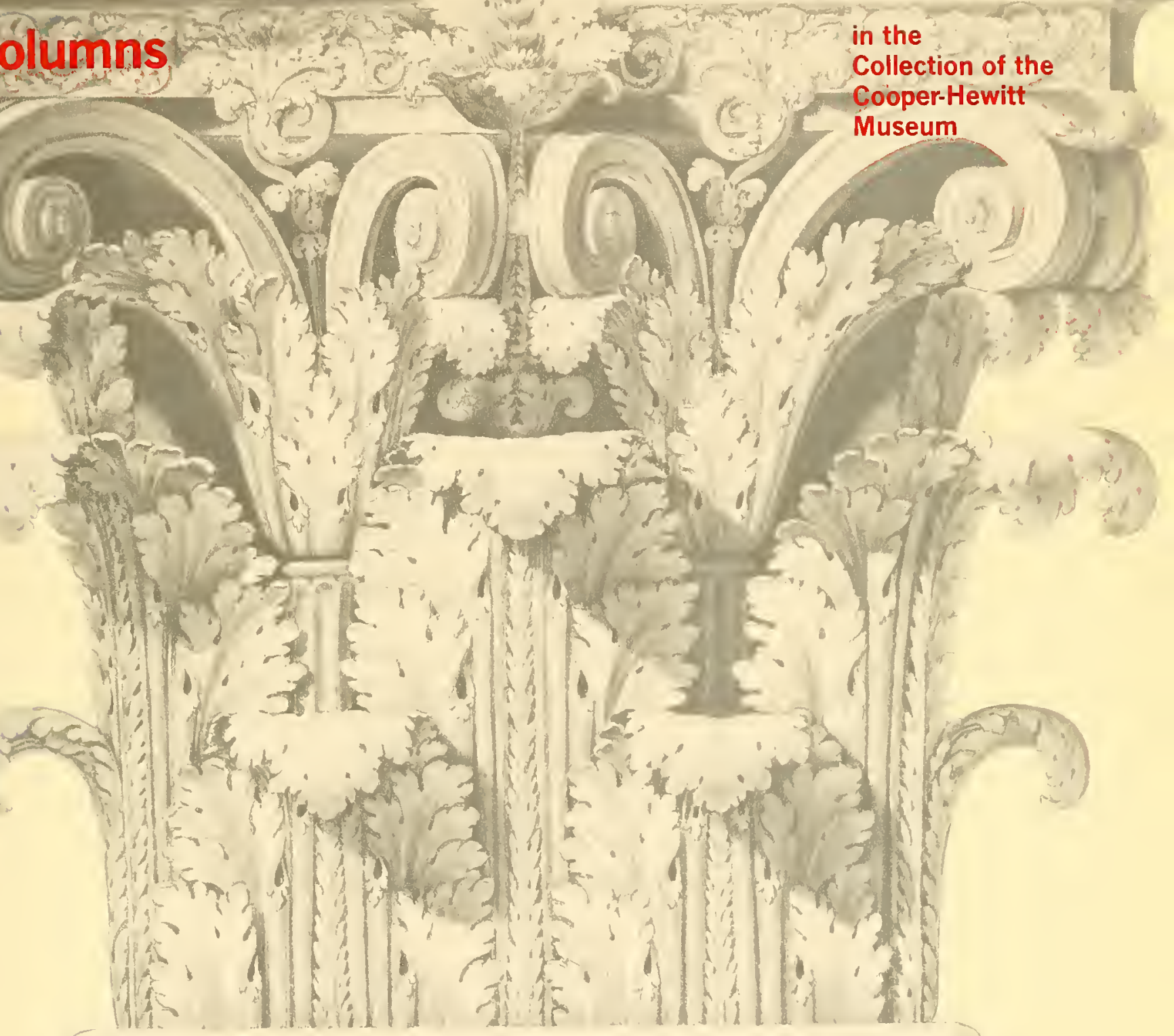

The Smithsonian Institution's National Museum of Design 
Copy after Giocondo Albertolli (1742-1839)

Italy

Corinthian Capital, 1798

Pen and brown ink, gray wash drawing

Purchase, Friends of the Museum Fund

1938-88-3388 


\section{Columns \\ c77

in the

Collection of the Cooper-Hewitt

Museum/

The Smithsonian Institution's National Museum of Design 
(c) 1982 by the

Smithsonian Institution

All rights reserved

Library of Congress

Catalog No. 82.072121

\section{Claude Perrault,}

translated by John James

A Treatise of the Five Orders of Columns in Architecture, London, 1708

Plate I: The Five Orders

Engraving

Gift of Abram S. Hewitt

Cooper-Hewitt Museum Library

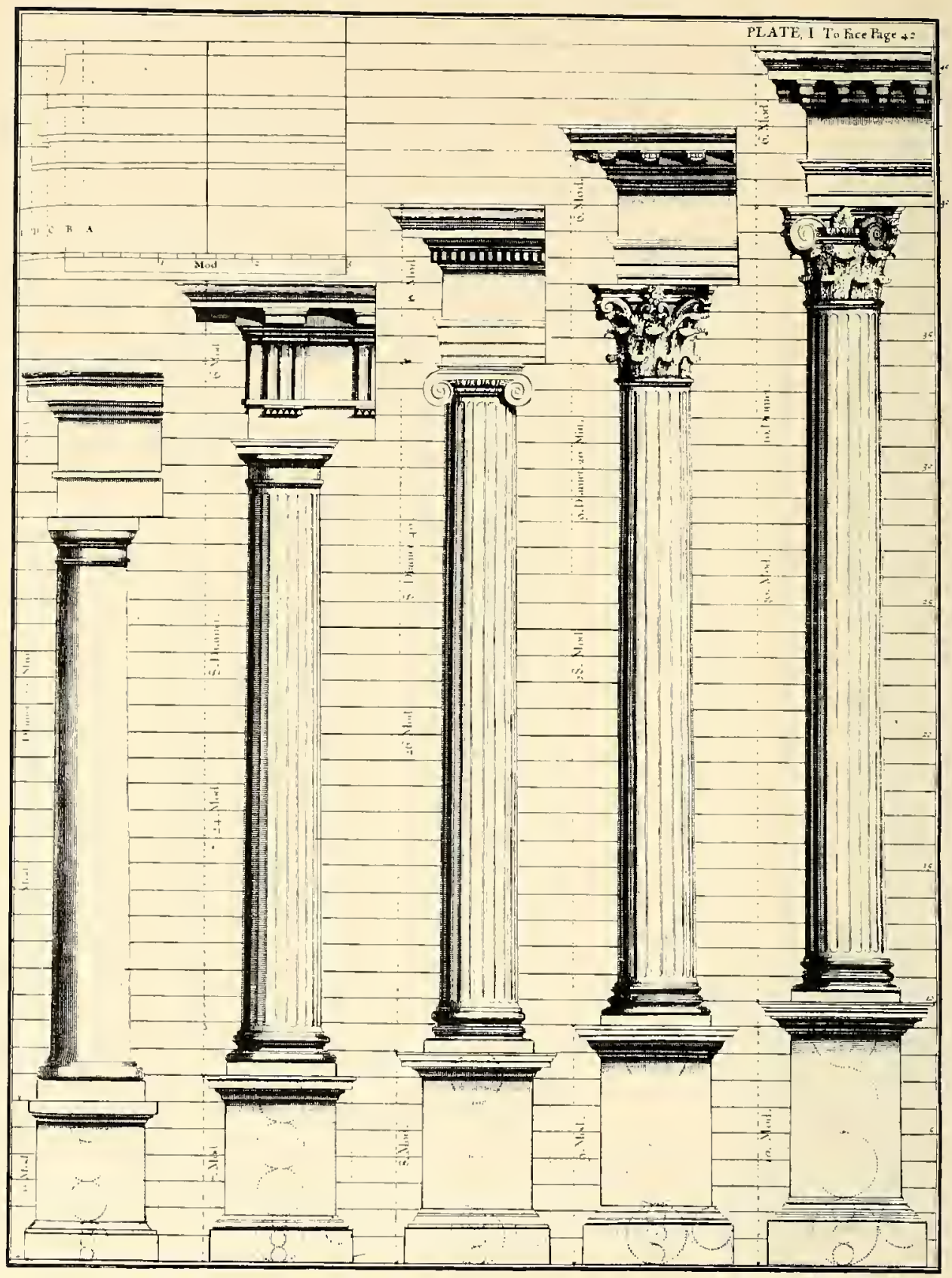



series of handbooks on objects in the Cooper-Hewitt Collection. The first set is devoted to specific collections; this one, like so many of the Museum's exhibitions, will focus on themes that cross departmental boundaries and have particular visual appeal.

The current revival of interest in classicial design has encouraged us to explore the column-which, throughout its long history, has enjoyed varying degrees of popularity, both as a structural support and as a decorative element. Columns, along with capitals, are richly represented in the Cooper-Hewitt Collection in drawings, prints, rare books, photographs, wallpapers, textiles, and utilitarian and decorative objects of all kinds.

This first publication in the new series was made possible through the kindness of two of the Museum's major benefactors, the Andrew W. Mellon Foundation and the Arthur Ross Foundation. Its appearance coincides with the showing of the exhibition The Column: Structure and Ornament, which was also generously funded by the Arthur Ross Foundation, long known for its dedication to classical architecture.

Lisa Taylor

Director 
Like many things of apparently simple purpose, columns are actually complex. Structurally, they are large posts erected to hold up roofs and ceilings, but artisticàlly and symbolically they serve other purposes. Columns are among the most persistent of architectural elements, having been superseded neither by the clustered piers of medieval churches nor the chaste, squared-off geometry of the frames of twentieth-century buildings. Columns have been made of many materials-marble, granite, and other stone, as well as wood, iron, and concrete. They were and are essential to classical architecture, and they have also been used as ornament on all manner of decorative arts, from desks and tables to clocks and candlesticks.

Columns, in their posture against gravity, speak first of support. They also imply shelter. since they almost always hold up a roof or ceiling. And, when a number of them are set in line, they form a screen, a subtle and suggestive device that mediates between the unstructured, relatively chaotic space of the outdoors and the more rational and comprehensible enclosed architectural space that lies beyond them.

Although there is little tangible evidence for the theory that the

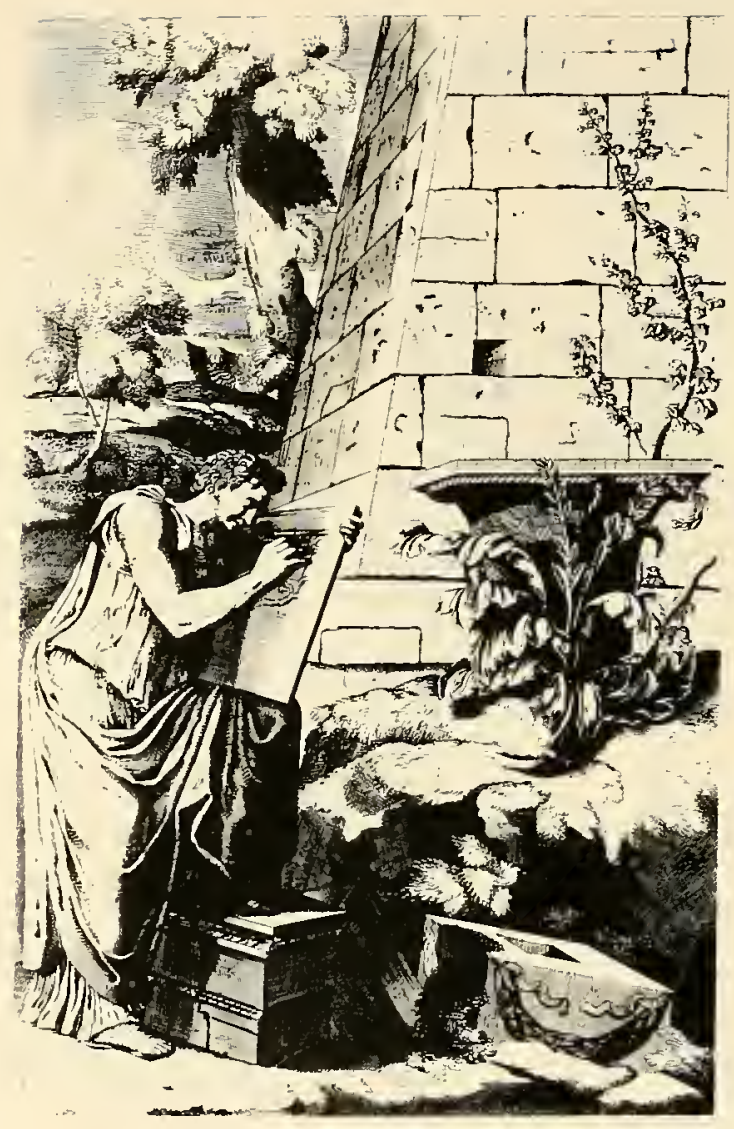

Roland Fréart de Chambray, translated by John Evelyn

A Parallel of the Ancient Architecture with the Modern, London, 1664

"Of the Corinthian Order"

Engraving

Cooper-Hewitt Museum Library 


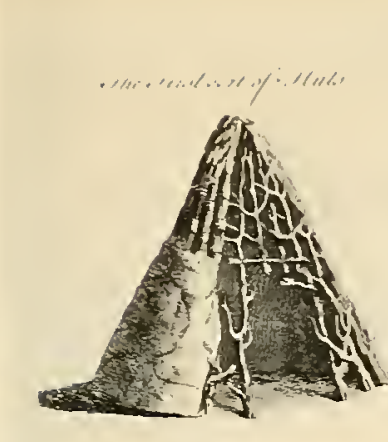

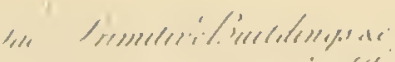
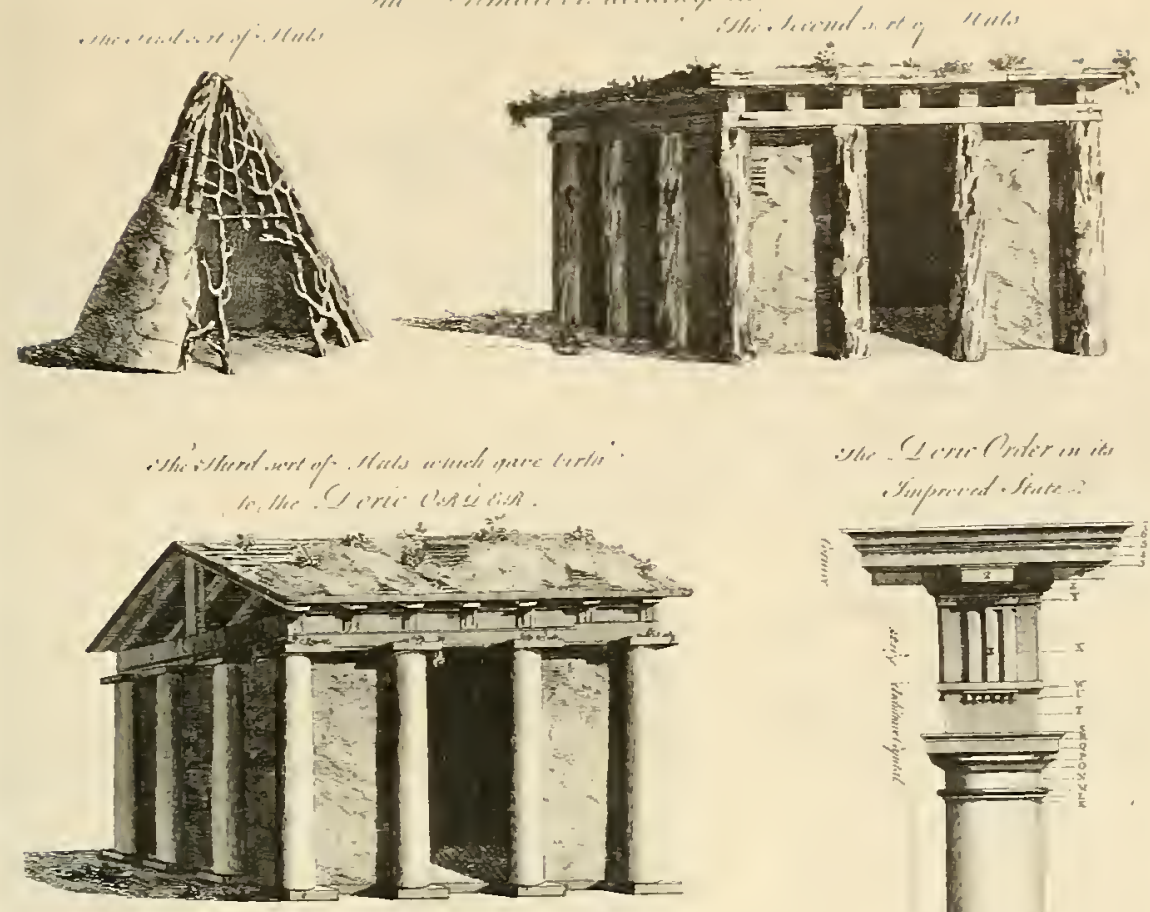

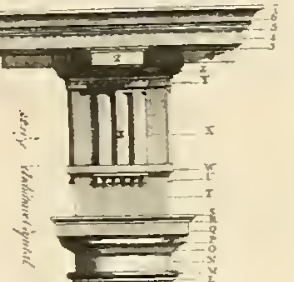

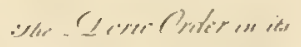

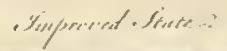

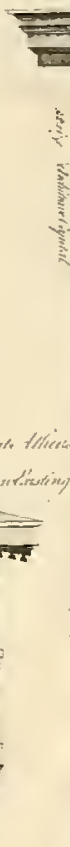

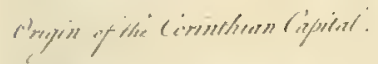

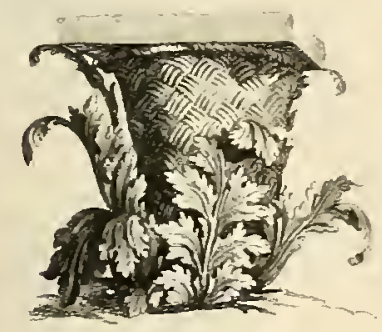



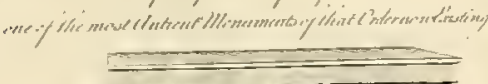
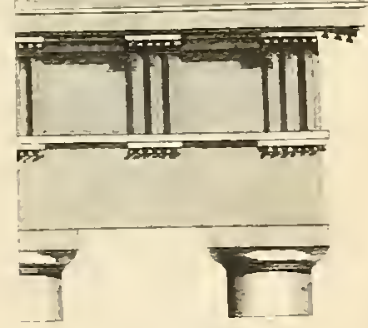

A L Privili c stillese urelgowe D. intair

E : Fillic

E limpe

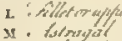

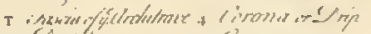
sthation

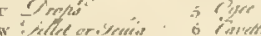

E Hoperi. Jerm

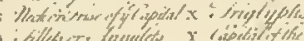
; : fillins

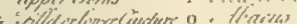
n e ceryer.

Q. Hexives

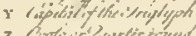

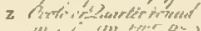

$\mathrm{A}$ : Aillit

William Chambers

A Treatise on Civil Architecture, London, 1759

"Of the Origin of Buildings"

Engraving

Gift of Hamill and Barker

Cooper-Hewitt Museum Library 
Claude Perrault, translated by John James A Treatise of the Five Orders of Columns in Architecture, London, 1708

Plate IV: The Ionic Order

Engraving

Gift of Abram S. Hewitt

Cooper.Hewitt Museum Library

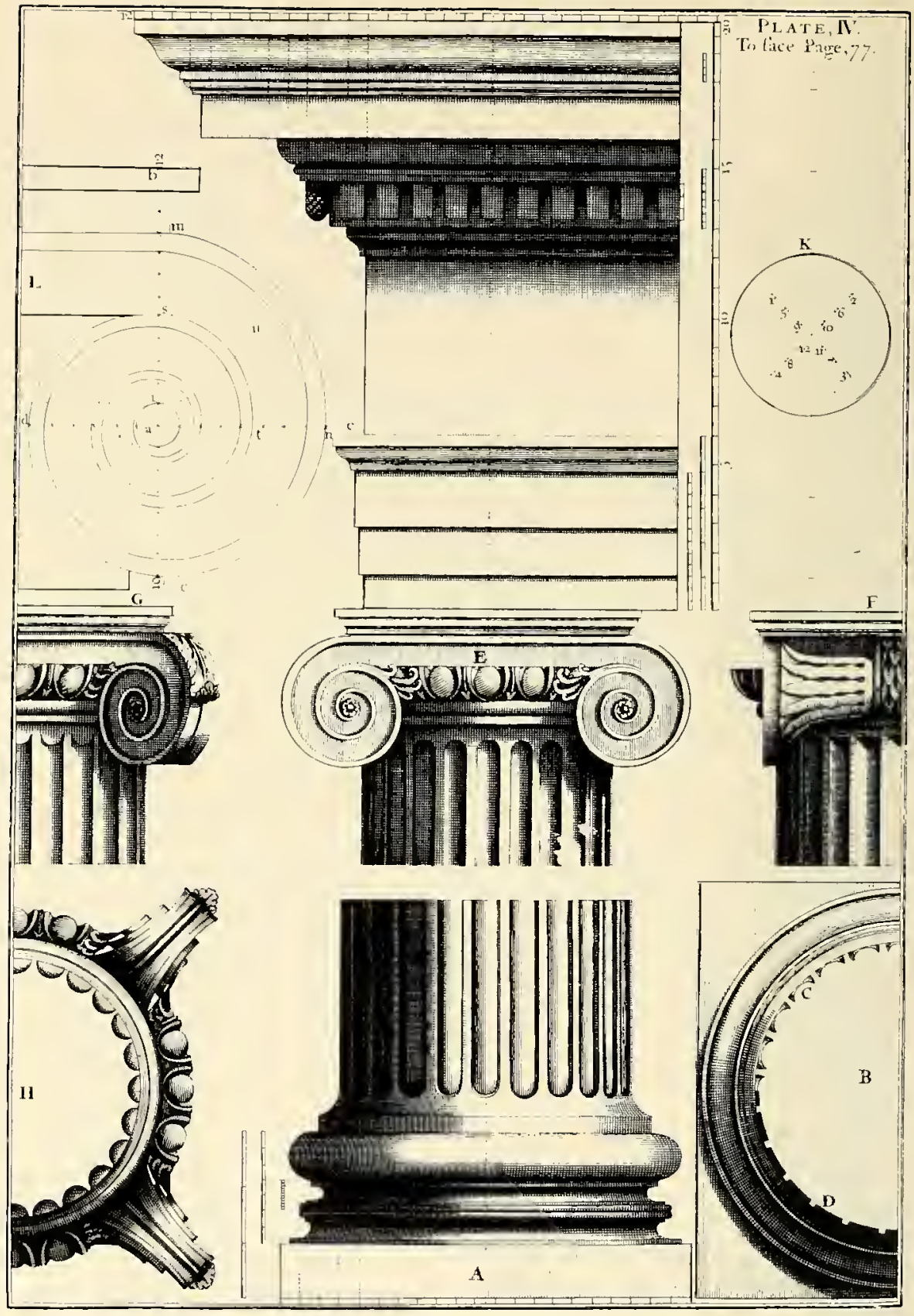




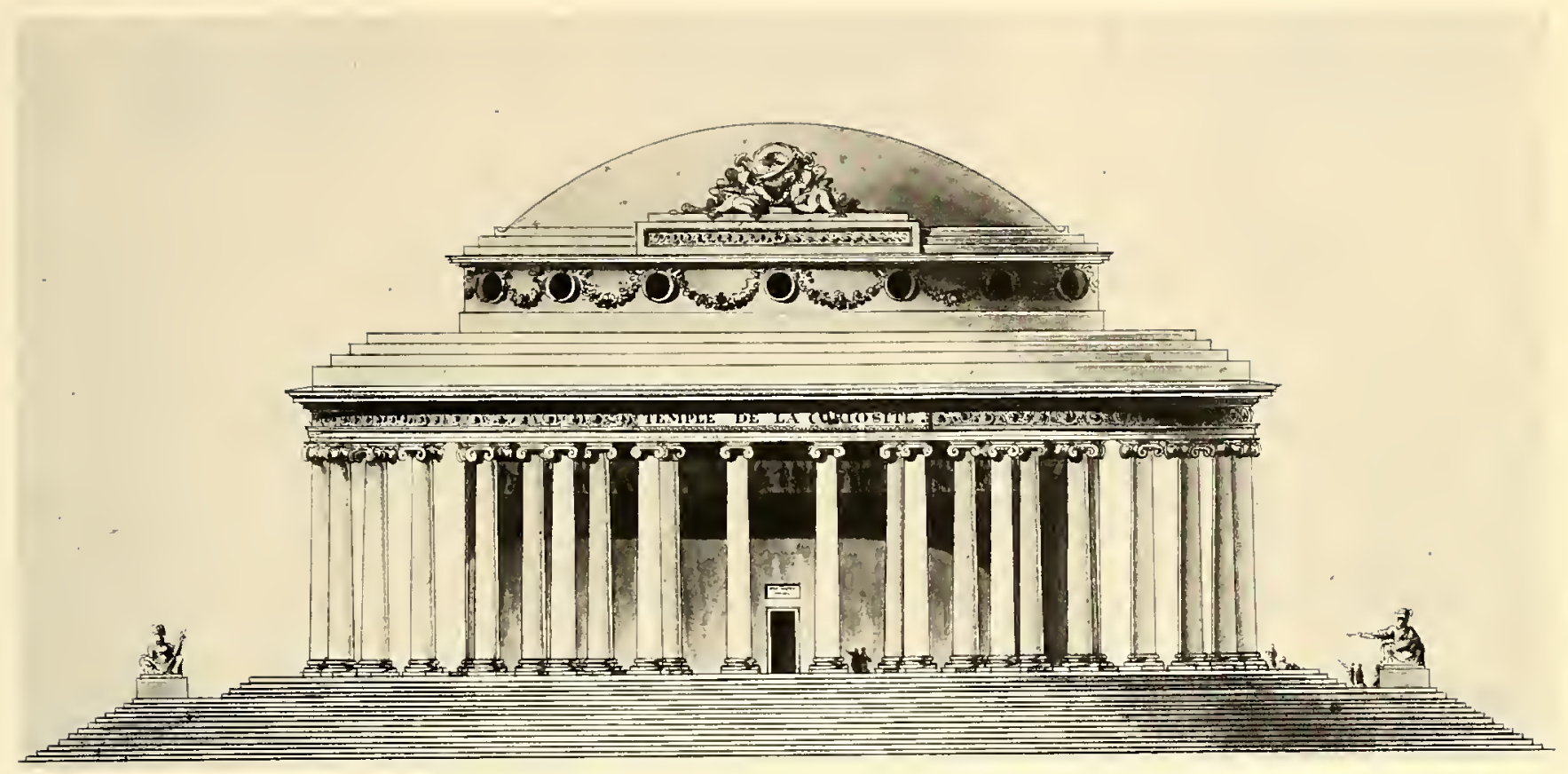

Circle of Etienne-Louis Boullée (1728-1799)

France

Temple of Curiosities

Pen and black ink, blue and brown wash

drawing

Gift of The Council of the Museum

1911.28-463 

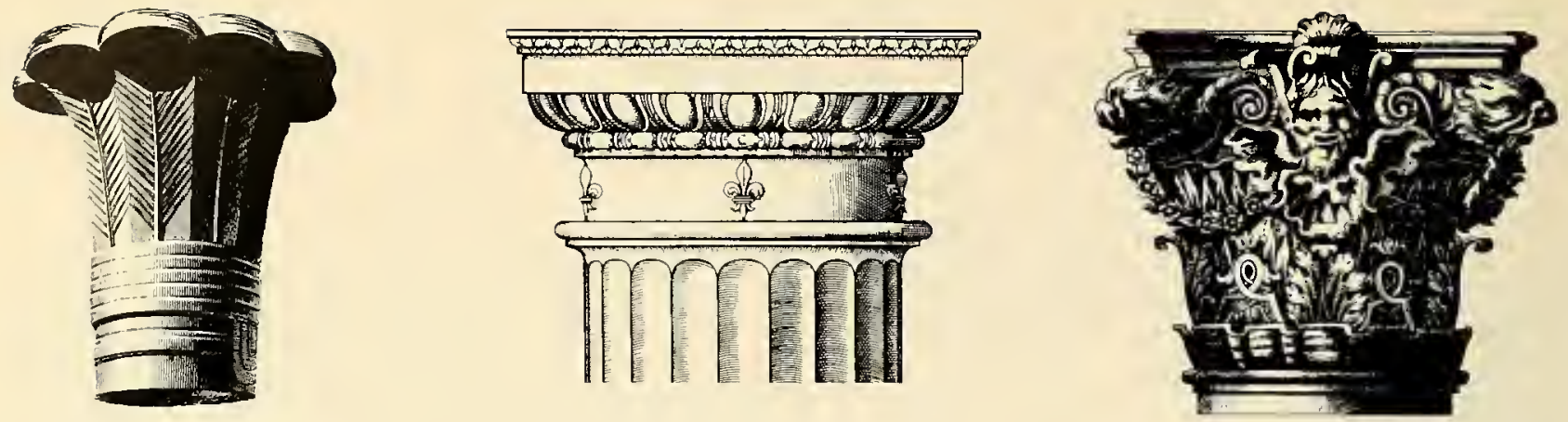

above left to right:

Egypt

Capital

Lithograph

Cooper-Hewitt Museum Picture Library

Giacomo Barozzi da Vignola

Regola delli Cinque Ordini d'Architettura,

1563

Plate XIII, Doric Order (detail)

Engraving

Gift of Henry O. Milliken

Cooper-Hewitt Museum Library

Capital from L'Art Décoratif,

Charles Claesen, Editor

Lithograph

Cooper-Hewitt Museum Picture Library

Cloister of Alcobaça

Portugal

Capital

Lithograph

Cooper-Hewitt Museum Picture Library

\section{Capital}

Lithograph

Cooper-Hewitt Museum Picture Library

Germany

Capital

Lithograph

Cooper-Hewitt Museum Picture Library 


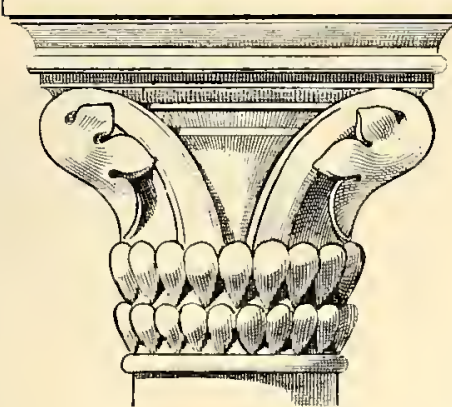

unsophisticated hut-by way of gradual refinement and artistic improvement-became the temple, the theory that primitive wooden roof-posts evolved into temple columns of stone is probably correct.

The celebrated basic Orders of classical architecture-Doric, Ionic, and Corinthian-appeared between the seventh and fourth centuries B.C., and, except during the Middle Ages, have been in use by architects ever since. Their appearance owed'something to the robust Egyptian columns of earlier times, which the Greeks, inveterate sea-voyagers, knew well. But neither the mammoth Egyptian temple supports, with bulging capitals of gathered plant-forms, nor the more elegant and slender sculptured half-columns that projected from solid Egyptian walls were more than shadowy sources for the early Greeks.
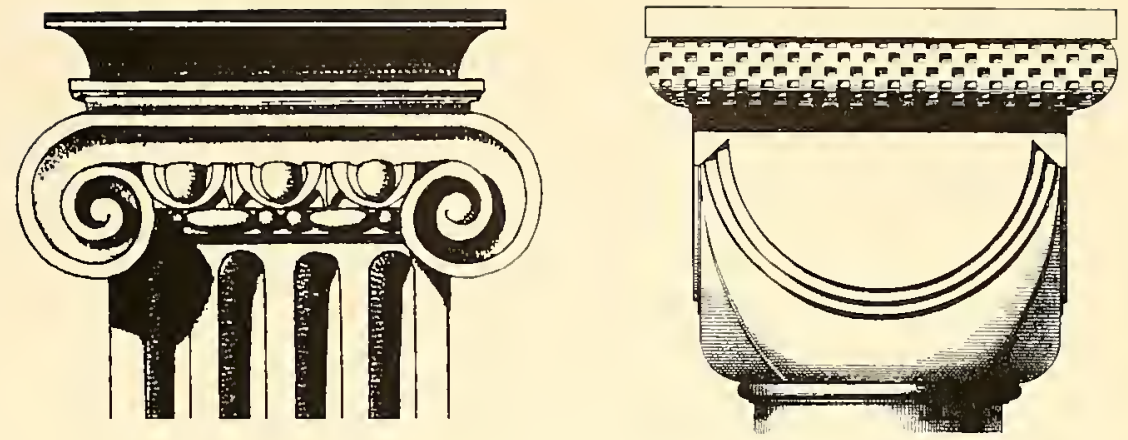

Greek architects and sculptors sought to express the essence of the column in its design. They began with an elegant but recognizable representation of the column's function-the support of the weight above it-by developing an abstract representation of the nature of the juncture between vertical load and horizontal support-the Doric Order. Soon came the later, more embellished and more organic shapes of the lonic Order-with its scrolled capital-and the Corinthian Orderwith its tall bell of acanthus leaves terminating in diagonally projecting small scrolls or volutes. By the fourth century B.C., the development of the Greek classical columns, with their extended families of mouldings and bases, was essentially complete, and classical Greek temples and sanctuaries, public colonnades, and other columned buildings could be seen in most Mediterranean lands. 

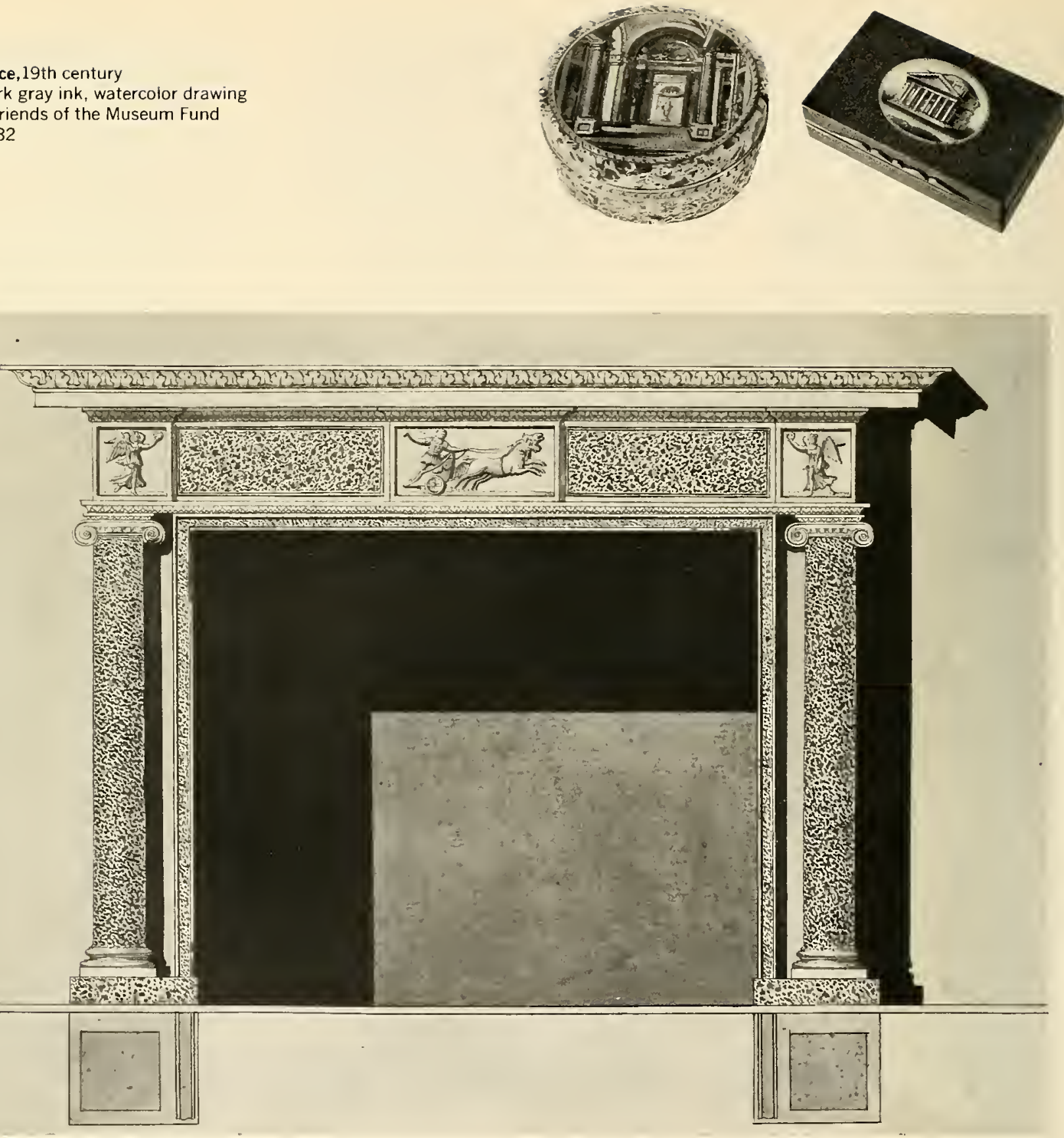
facing page, top:

Italy

Snuff Box, 19th century

Variegated agate, stone mosaic, gold

mounts

Gift of Miss Susan Dwight Bliss

1967-48-14

Italy

Snuff Box, about 1840

Green porphyry, stone mosaic, gold mounts

Bequest of Sarah Cooper Hewitt

1931-6-24

below:

England

Birdcage, mid.19th century

Mahogany veneer, curly maple, and wire

Gift of Sarah and Eleanor Hewitt

1916-19-82
The Romans, when they took over these lands, were anxious to acquire a veneer of Greek culture and adopted the Greek Orders.

They quickly began making changes in them, however, that became important for the history of Western architecture.

The fundamental parts of all the Orders are the same: base (missing in the Doric Order), shaft, capital, mouldings, and small lightand-shade details differing for each Order. In general, the complexity of the capital determines the complexity of the other parts. The height of the shaft is based on its diameter. Usually the shaft is six to eleven diameters high, depending on the Order. The capital should be recognizably one of the Orders, although the details and profiles can vary considerably. The Romans added the Composite Order, which has a Corinthian capital topped with large, prominent Ionic scrolls, as well as figured capitals and other variations and permutations. Variations in the essential shapes appeared in later ancient timestwisted forms, vine-clad shafts, and highly idiosyncratic capitals.

Slight changes in the ratio between the width and height of a column can lessen, if not destroy, the harmony and effectiveness of the design. The column itself, if it is not to appear mechanical and 

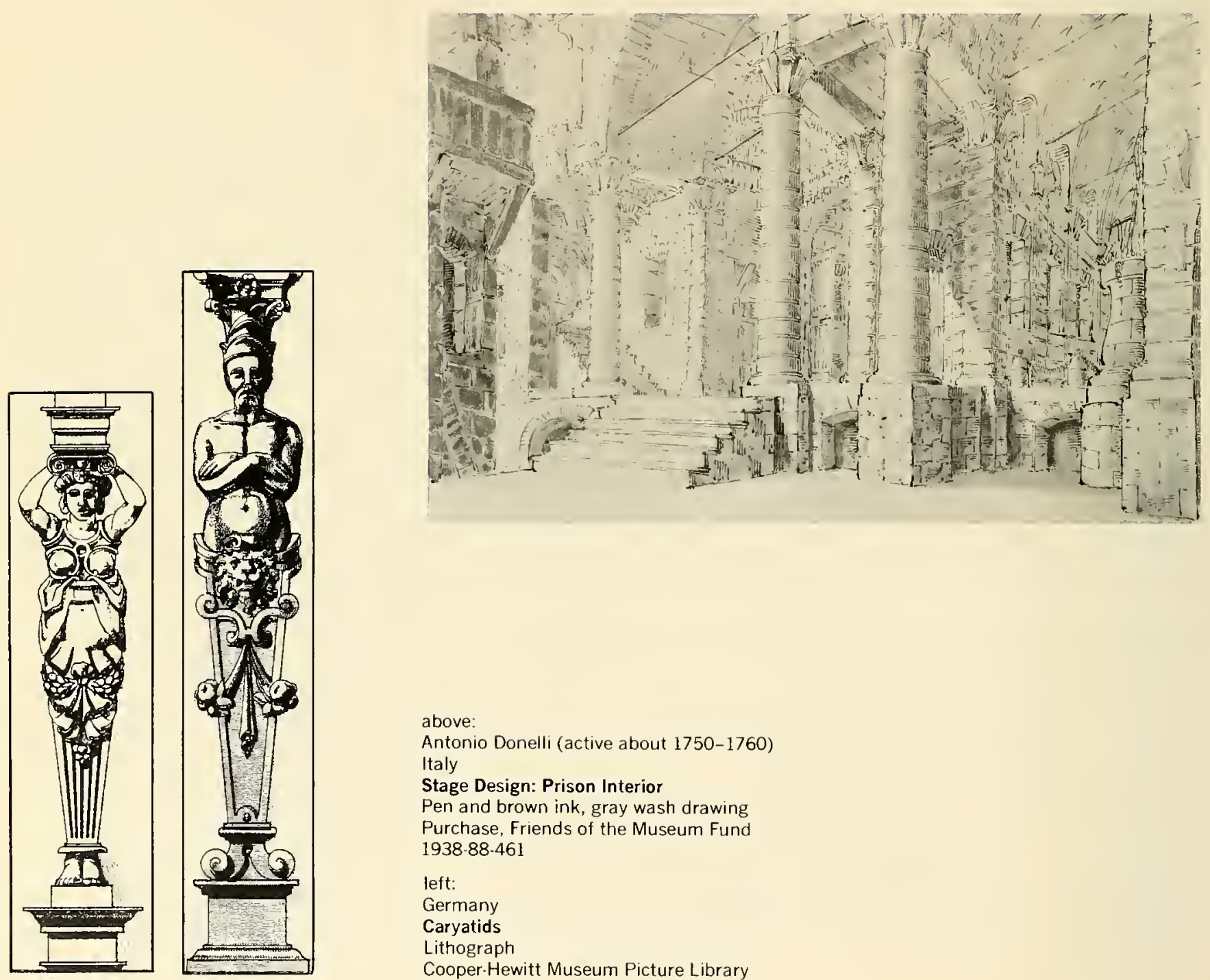

above:

Antonio Donelli (active about 1750-1760)

Italy

Stage Design: Prison Interior

Pen and brown ink, gray wash drawing

Purchase, Friends of the Museum Fund 1938-88-461

left:

Germany

Caryatids

Lithograph

Cooper-Hewitt Museum Picture Library 
Italy

A Twisted Column, 18th century

Pen and brown ink, gray wash, slight traces of pencil drawing

Purchase, Friends of the Museum Fund 1938-88-3720

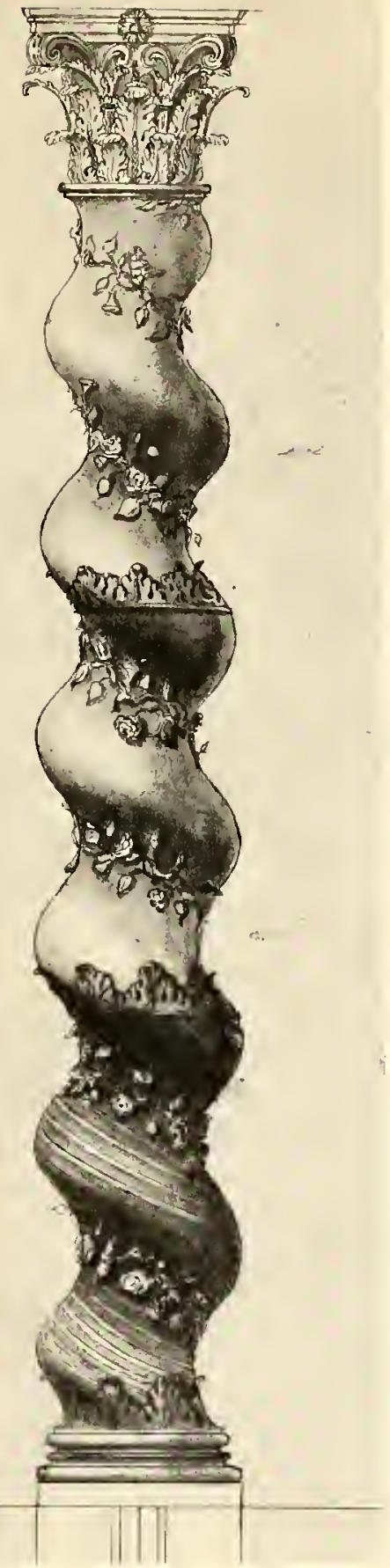




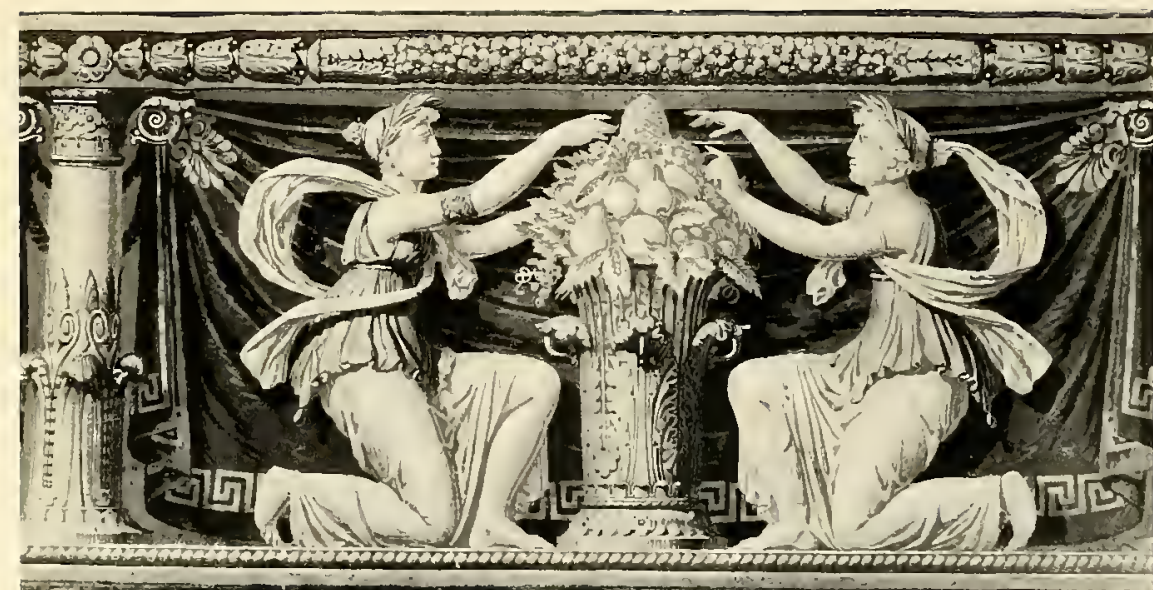

$v x_{103}$
Probably by Joseph Dufour (1752-1827)

France

Wallpaper, about 1805

Woodblock printed

Gift of John Judkyn in memory of his mother, Florence Judkins

1953-213-1 unsupple, must taper slightly as it rises to its capital. And this tapering, if it is not to appear rigid and uninteresting, must actually be curved subtly in silhouette. This effect, known as entasis, although it can go unnoticed by the untrained eye, gives the column a graceful appearance.

In antiquity columns were made of marble when resources permitted, but often a local stone that would take and hold a sharp edge was used. Colored marbles, tinted granites, and fairly rare stones were favored by the Romans, both in Rome and in the provinces. Shafts might be monolithic or built up from carefully fitted cylindrical drums. By the second century A.D., columns and other elements of decoration appeared in terra cotta, for by then the Orders were a part of all aspects of architecture, and what we now call classicism was as common in non-institutional and vernacular buildings as in the grand monuments most commonly associated with it.

The decision of whether or not to flute the column, that is, to channel the shaft vertically, is also complicated and depends on a number of factors: the amount of light that will fall on the column and the direction from which it will come, whether or not the architect 


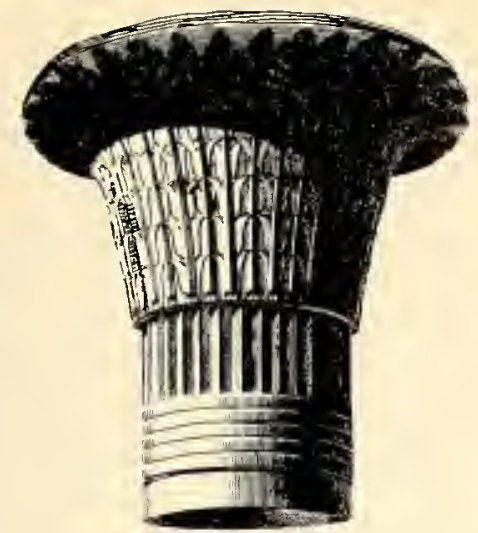

above:

Egypt

Capital

Lithograph

Cooper-Hewitt Museum Picture Library

right:

J. Zuber et Cie.

Rixheim, Alsace, France

Two panels from El Dorado, early 20th. century edition of the wallpaper originally printed in 1848

1540 hand blocks on paper

Gift of Dr. and Mrs. William Collis 1975.77.9. -10

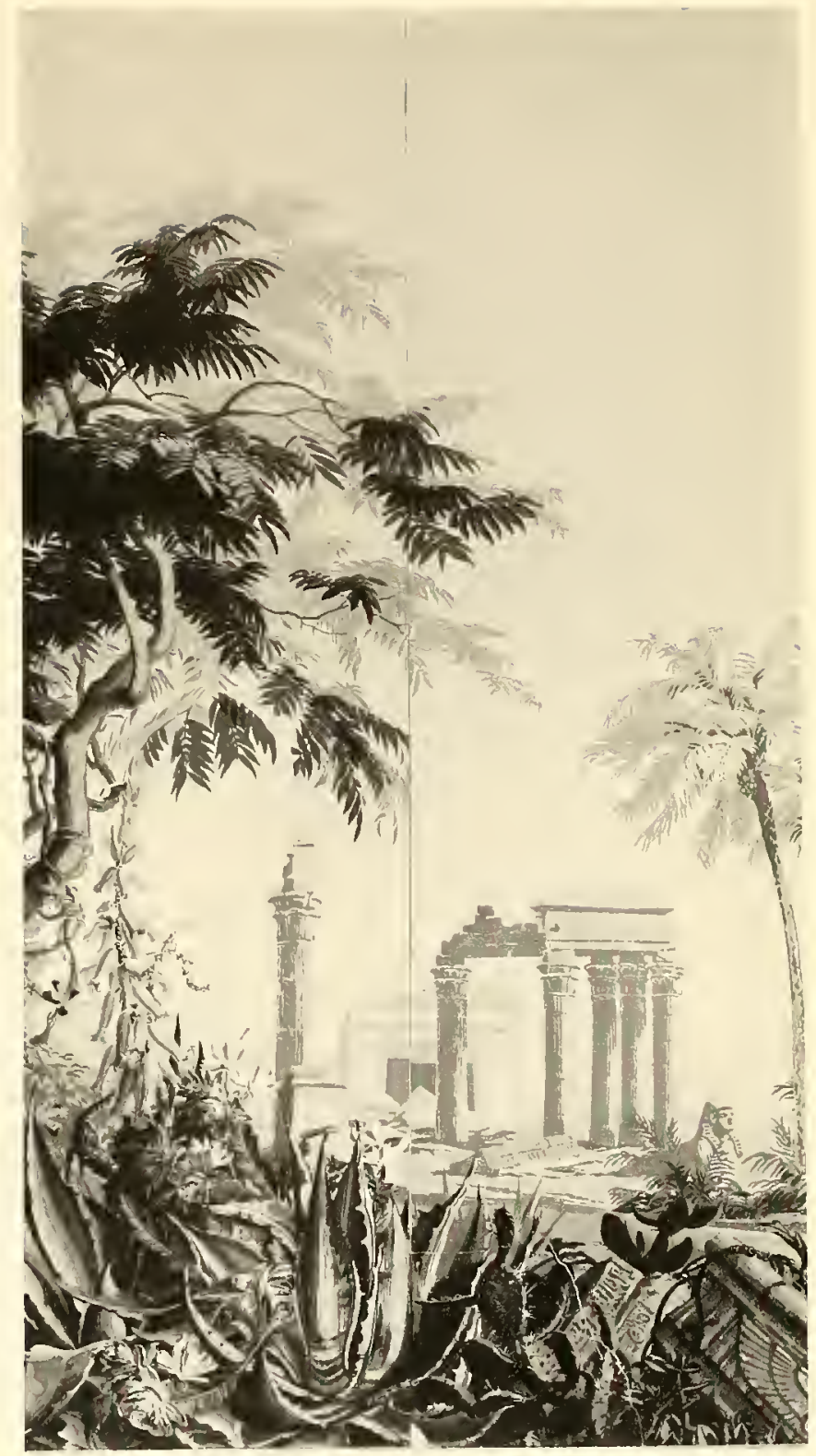




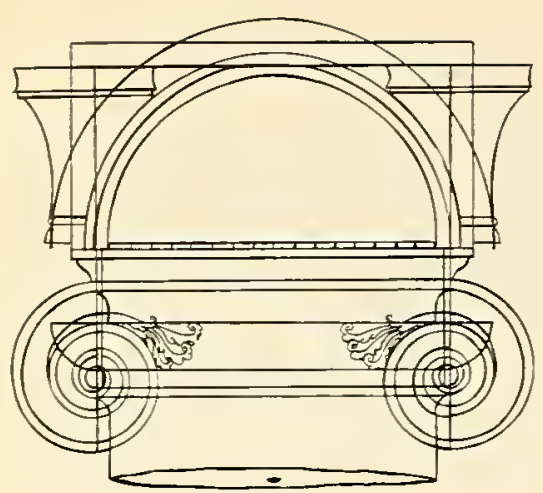

above:

Pollio Vitruvius, Commentary by Daniello

Barbaro

I Dieci Libri dell'Architettura, Venice, 1556

Woodcut: Ionic Capital

Cooper-Hewitt Museum Library

right:

Charles-Louis Clérisseau (1722-1820)

France

Figures Near a Ruined Colonnade, 1761

Pen and black ink, brown and gray wash, white gouache drawing

Gift of Mrs. Howard J. Sachs and Peter G.

Sachs in Memory of Edith L. Sachs

1978-168-42

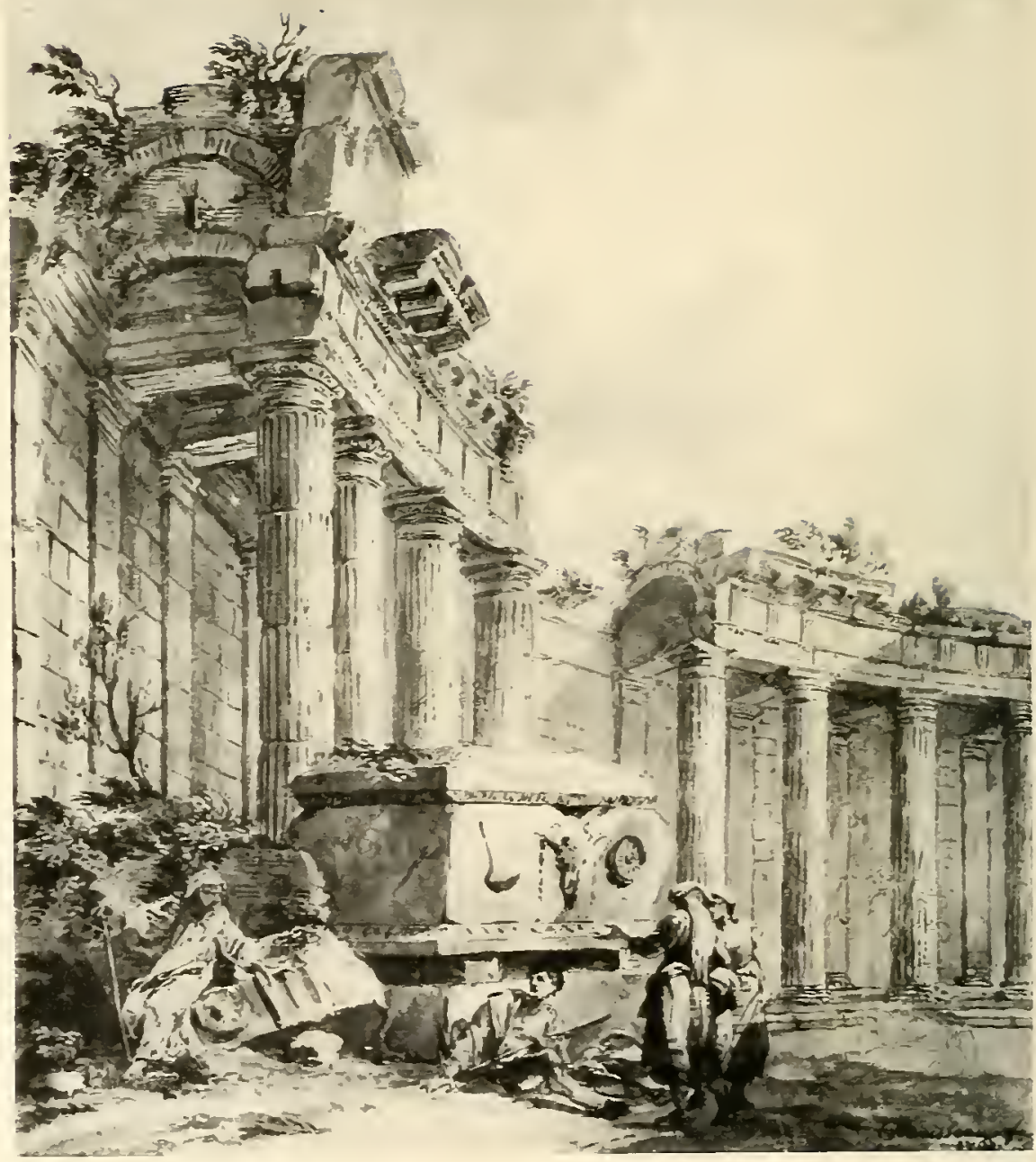


wishes to emphasize the vertical aspects of his design, and other considerations. In view of these things, it is not surprising that a body of rules, sometimes all but impenetrable, has grown up to guide the less inspired in the correct use of the column. The story of these rules is more interesting than the rules themselves, which had to do with proportion, spacing between columns, and profiles and assemblies of mouldings. The process began as soon as the principles of the Greek Orders were established, but the only ancient book of rules we have to refer to is that of the Roman architect Vitruvius, who wrote an inordinately influential treatise. The Ten Books on Architecture, in about 25 B.C., early in the reign of Augustus Caesar. Manuscript copies of his work survived the Dark Ages, and after A.D. 1400 his work became a bible, to be quoted, puzzled and argued over, and ignored or followed according to time or taste. Today we know that Vitruvius, far from representing fairly the architecture of his time, was a very conservative man, proud of the knowledge he acquired in the field and in the library, but hardly receptive to the striking innovations of his day. He never mentions the grand experimental buildings of
Léonhard Chailleat, called Leonardo Scaglia (active 1640-1650)

France, worked in Italy

Composite Capital with Figures

Pen and brown ink, brown wash drawing

Purchased in Memory of The Council of the Museum

1947.57 .3
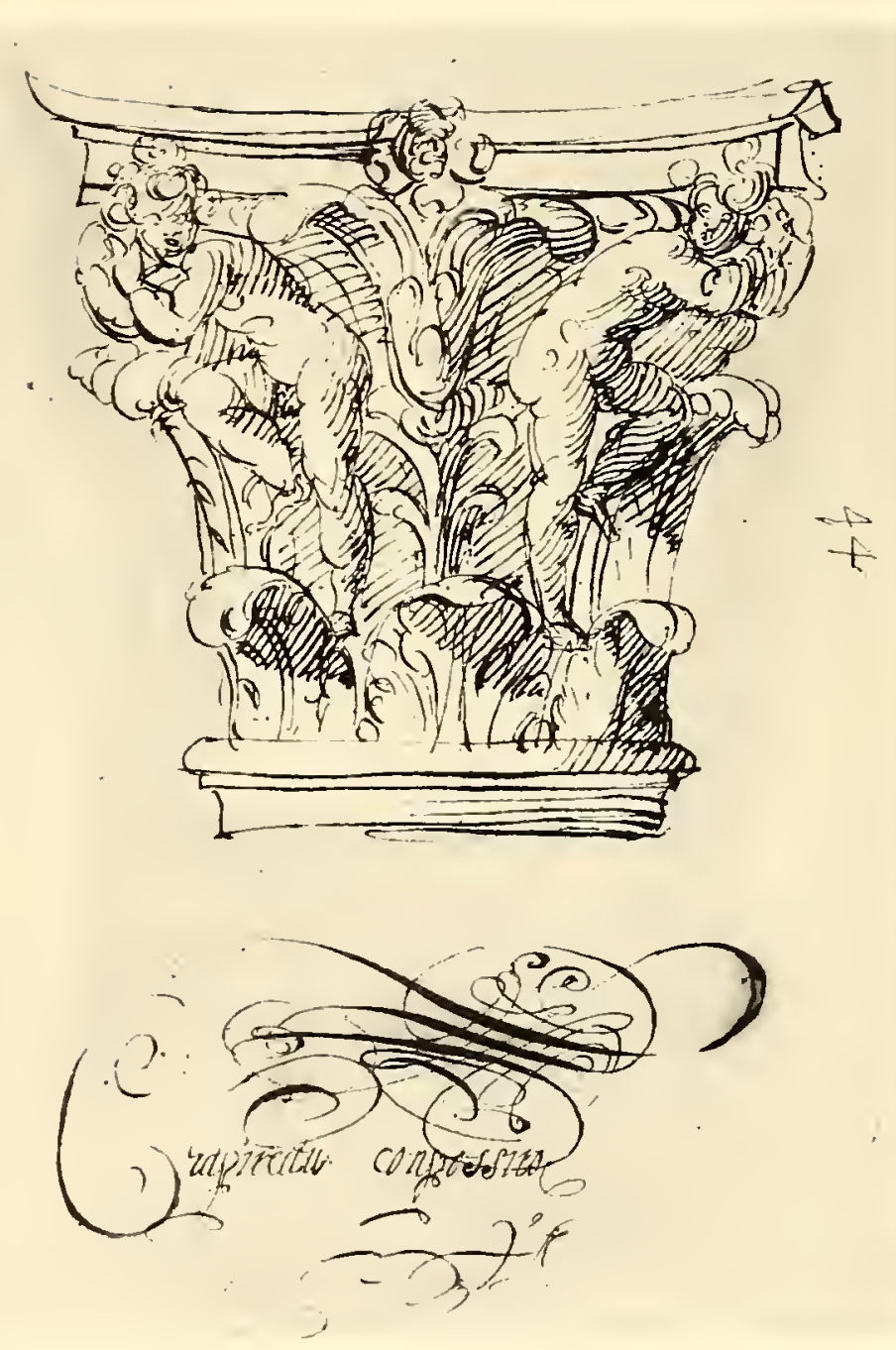


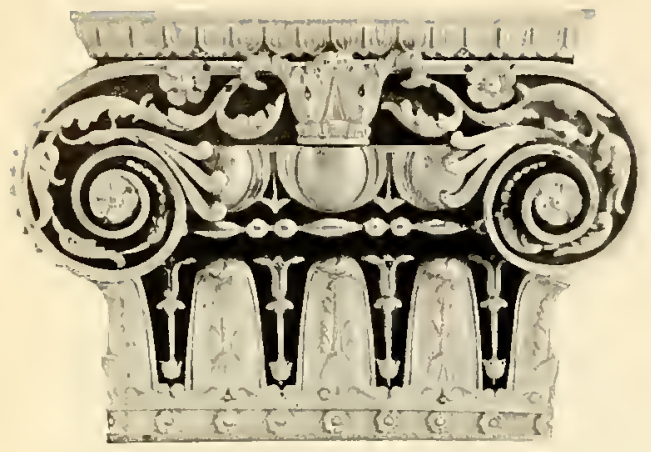

Rome and its environs that pointed the way toward a new and vital spatial architecture to which the Orders would be adapted by Roman imperial architects. Instead, he gives much practical information about construction and a kind of embalmed codification of rules by which he and other less than inventive conservatives might achieve an adequate, respectable classicism.

This is not to say that Vitruvius's work is without value. On the contrary, it contains much precious information otherwise unrecorded. In the Renaissance his text became a kind of touchstone of propriety. But because Vitruvius wrote before the chief monuments of ancient Rome were built, before Roman reorchestrations of Greek elements had appeared fully defined, much of his text could not be coordinated with what Renaissance architects could see and measure. Vitruvius's bias in favor of later Greek design had, through the accident of its preservation, put into the hands of Renaissance architects a work that they valued more for its authenticity as a genuine ancient text than for its content. Soon they began making their own rules for the Orders, the famous regole, which, though acknowledging Vitruvius's primacy, departed from his prescriptions-as his Roman successors had done-with impunity. Thus successive architects, from the mid.fifteenth century onwards, produced books of rules wherein they invoked the name of Vitruvius, a process that continued at least until early in the present century. Giacomo Barozzi da Vignola in the sixteenth century, Claude Perrault in the seventeenth, and many others wrote their own variations on Vitruvius; their names appeared on the title-pages of their followers, and thereby kept alive the Vitruvian rules, especially those for the design and proportions of columns.

Almost from the earliest times columns have been used on a variety of buildings, and it might be said that they are a symbol of the hallowed origins of Western Civilization, rather than an indication of the function of a building. The temple, the church, the bank, and the house have all made use of the column. 

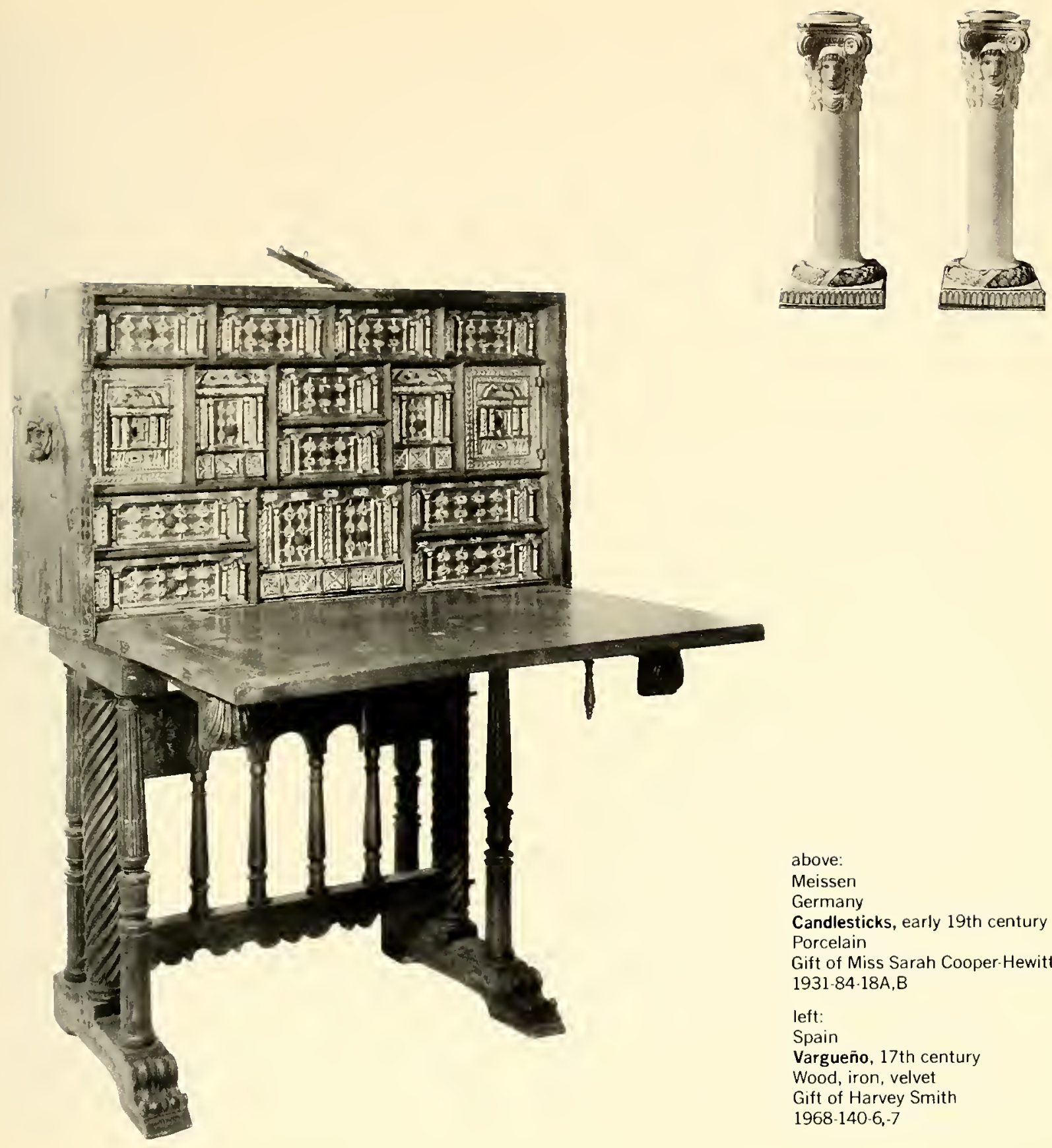

above:

Meissen

Germany

Candlesticks, early 19th century

Porcelain

Gift of Miss Sarah Cooper-Hewitt

1931-84-18A,B

left:

Spain

Vargueño, 17th century

Wood, iron, velvet

Gift of Harvey Smith

1968-140-6,-7 
The column is related to the engaged column and the pilaster, both of which are really parts of walls but have the components and silhouettes of columns. The engaged column projects from a solid wall in a more or less halfround shape; the pilaster is flat and projects less. Pilasters are often found on walls directly behind fully round, free-standing columns, an ingenious device that responds to and reinforces the column's powerful sense of presence.

Engaged columns and pilasters give the architect tools with which to break up and articulate otherwise largely unfeatured wall surfaces, giving them a rhythmic implied division that can lessen the monotony of a structural solid. They are also used in defining openings in walls by flanking them or dividing one opening from another. Pilasters and mouldings are often more subtle than they may at first seem, in part because of the shadows created by the details of their form. A properly classical building without mouldings is unthinkable because the play of light and shadow on these forms lies at the heart of the visual definition of architectural form.

Other than for certain memorial purposes, columns rarely stand alone. They usually appear in
Desfossé et Karth

France

Pilaster from a set of wallpapers entitled Régence, 1863-1865

Woodblock printed

Gift of A. Germain

1955-3-3

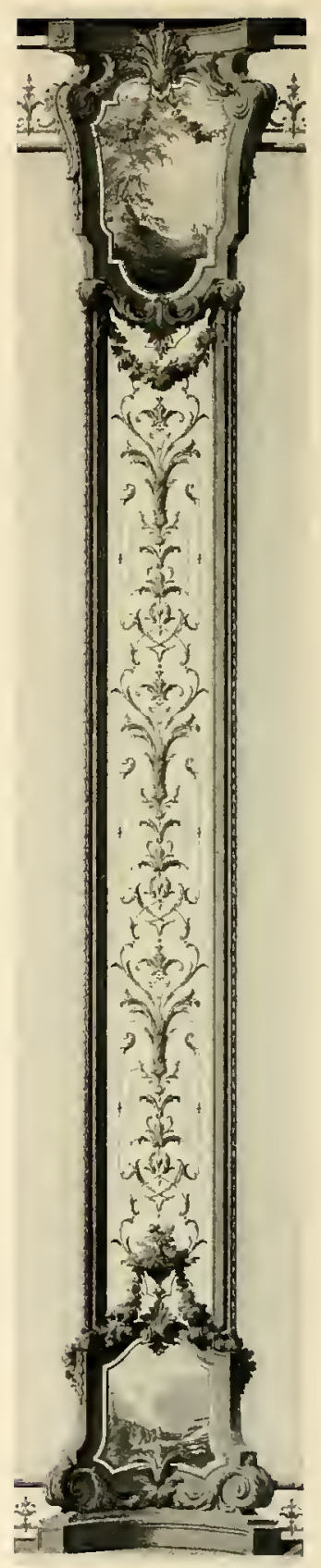




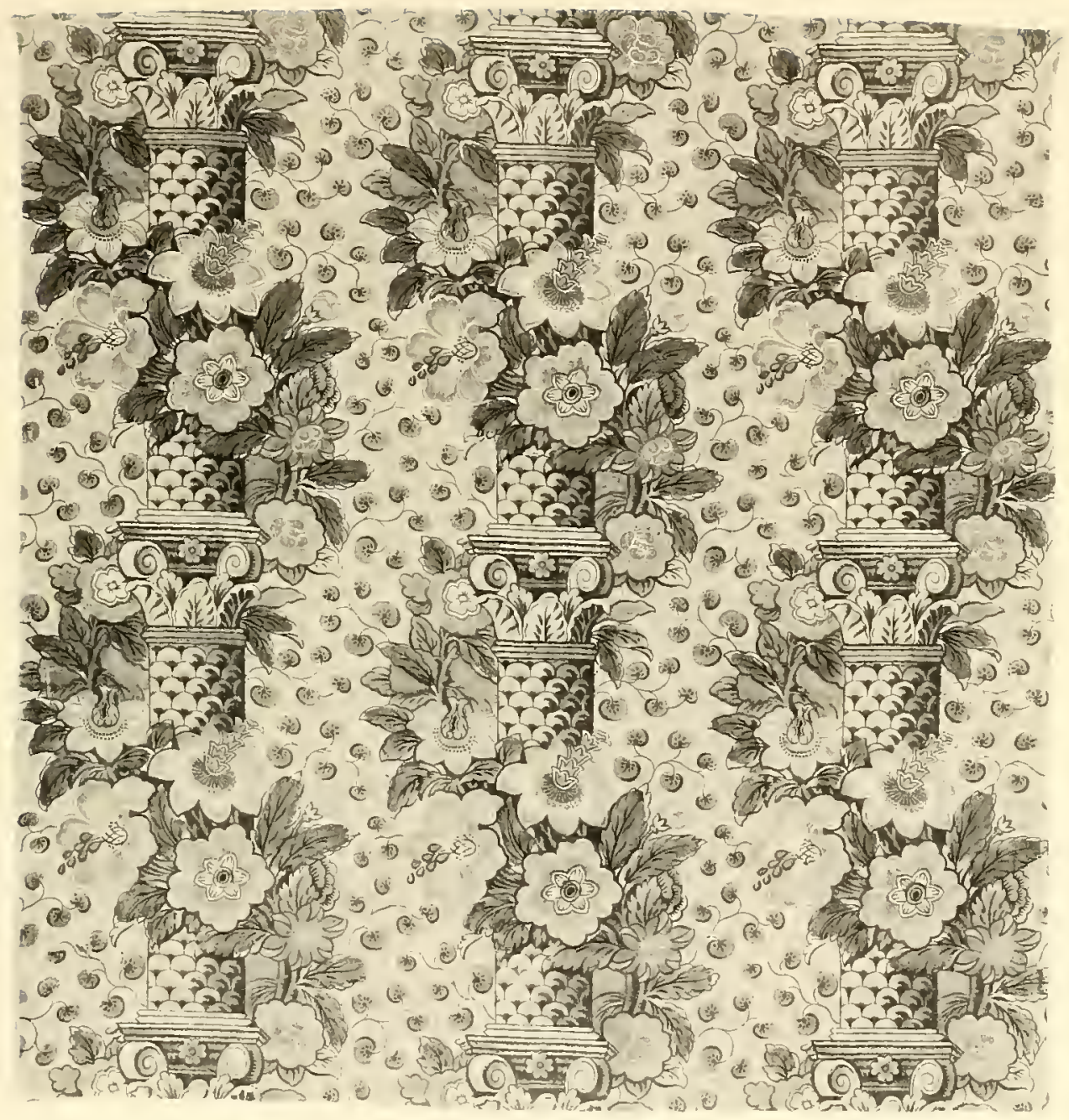

England, about 1812

Hand block printed fabric

Cotton, plain weave

General Museum Purchase Fund

1975-60-32 


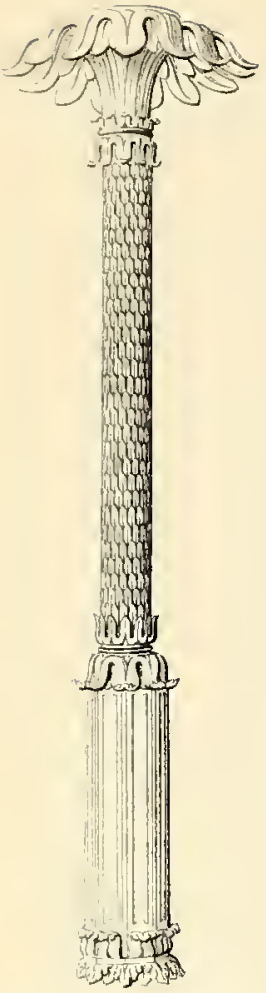

above:

John Nash

Illustrations of Her Majesty's Palace at Brighton, London, 1838

Plate 23: Banquetting Room Gallery, or Green Drawing Room, (detail) Engraving after Augustus Pugin (1762-1832)

Purchased in Memory of

The Council of the Museum 1951-128.1(23)

right:

John Nash

Illustrations of Her Majesty's Palace at Brighton, London, 1838

Plate 5: Center Part of the Steyne Front Engraving after Augustus Pugin (1762-1832)

Purchased in Memory of

The Council of the Museum 1951-128-1(5) 
France

Column with Statue of Napoleon, Place Vendôme, Paris, about 1850 Woodblock printed

Gift of Sarah and Eleanor Hewitt 1928.2.91

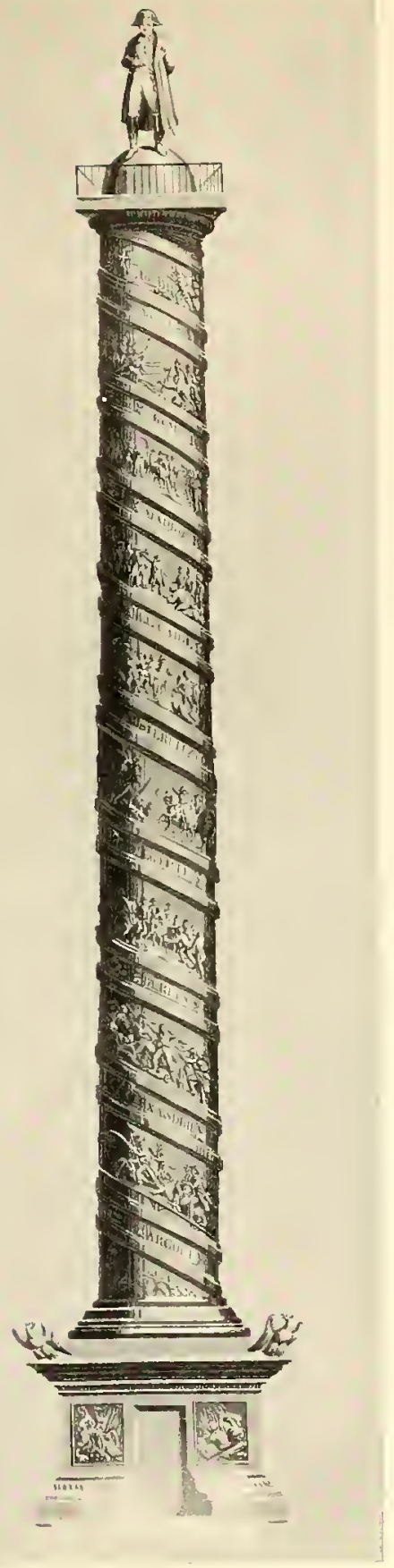


file, set out along a straight line, or are used in pairs if they are not part of a facade supporting a triangular gable or pediment. This composition appears in a great variety of sizes, from the small niche in a church or house to majestic facades rising sixty to eighty feet in the air. Sometimes columns are set along curves, creating an ever-changing and complex pattern of relationships as the observer moves toward or around the building. All these combinations are of ancient origin, and all have been used in seemingly endless variety.

The Romans, after a number of trial attempts, perfected the marriage of columns with arches and added it to the basic classical repertory that had been established by the Greeks. The Romans also combined the column with the vault, an equally important development for the history of architecture. In such combinations, the column might be structural, an actual working member of a building, or purely visual, an element added for its symbolic value or in order to give a rhythmic vertical organization to the interior of a vaulted building.

While the Greeks had mixed the Orders, as in the celebrated fifth-century B.C. Temple of Apollo at Bassae, it was the Romans who

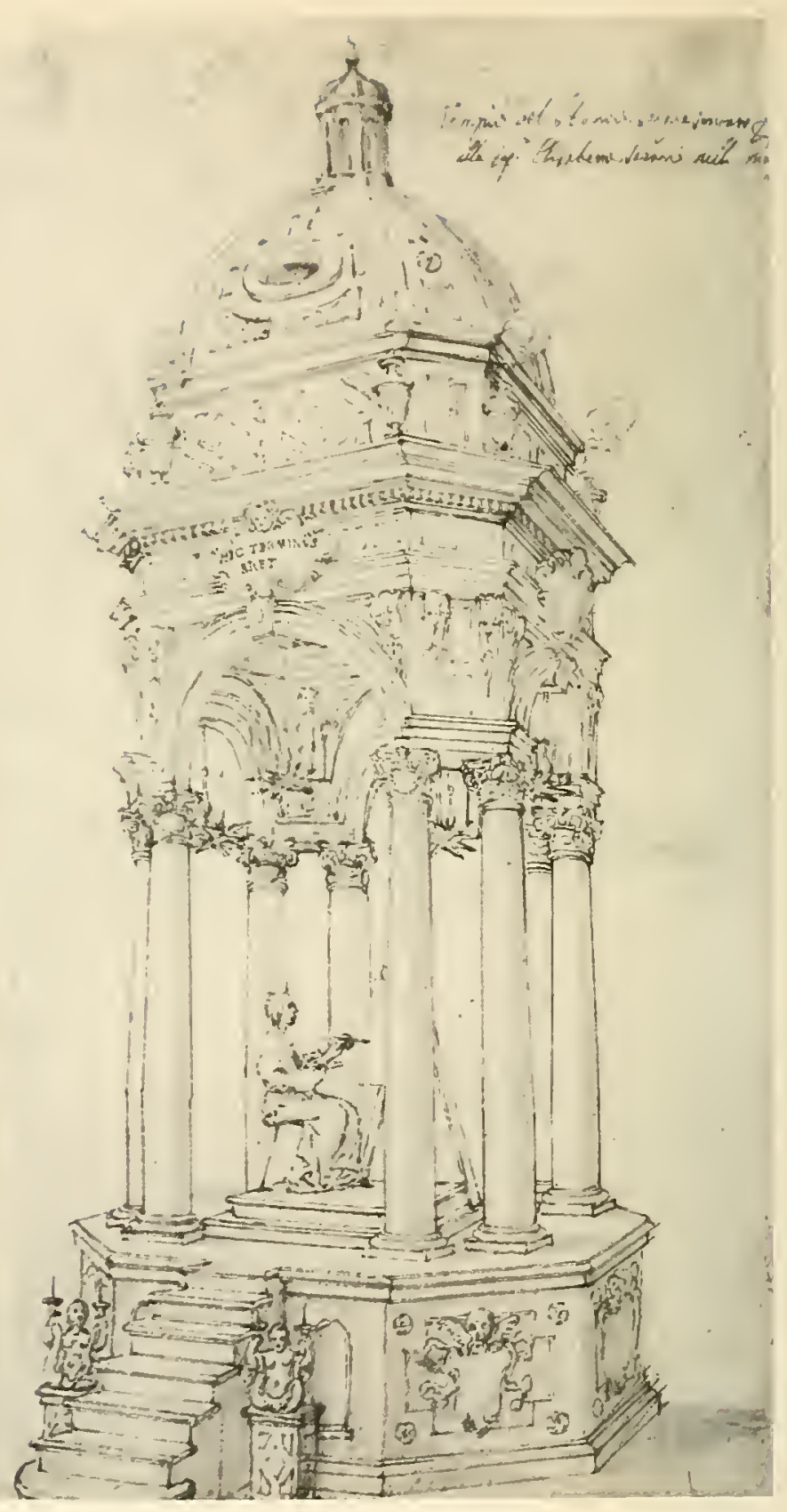


facing page:

Matteo Borboni (about 1610-1667)

Italy

Catafalque of Elisabetta Sirani, 1665

Pen and brown ink, brown wash, red and

black chalk drawing

Purchase, Friends of the Museum Fund

1938-88.2503

right:

Leon Battista Alberti

L'Architettura, Florence, 1550

Woodcut: Basilica, Interior Façade

Cooper-Hewitt Museum Library
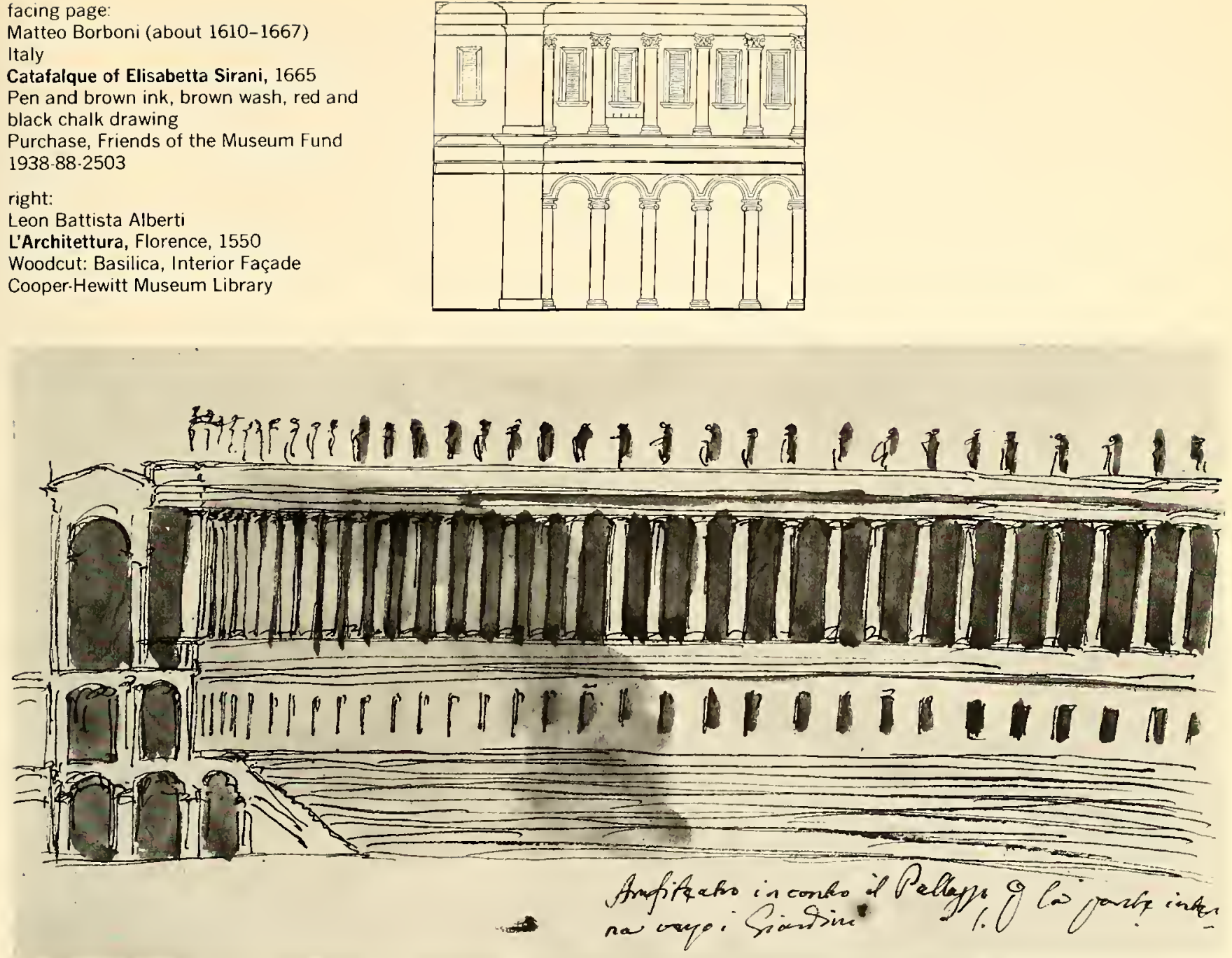

above:

Giuseppe Barberi (1746-1809)

Italy

Amphitheater with a Colonnade

Pen and brown ink, brown wash drawing

Purchase, Friends of the Museum Fund

1938-88.1170 
below:

Frederic Edwin Church (1826-1900)

United States

Column Drums from the Parthenon, 1869

Oil sketch

Gift of Louis P. Church

1917.4-574 A facing page; top:

Oliver Smith (born 1918)

United States

Stage Design: North African Coast, for

Maiden Voyage, 1955

Pen and black ink, pencil and

watercolor drawing

Gift of Oliver Smith

1969-171-4

facing page, bottom:

Italy, Rome

Arch of Gallien

Engraving

Cooper-Hewitt Museum Picture Library





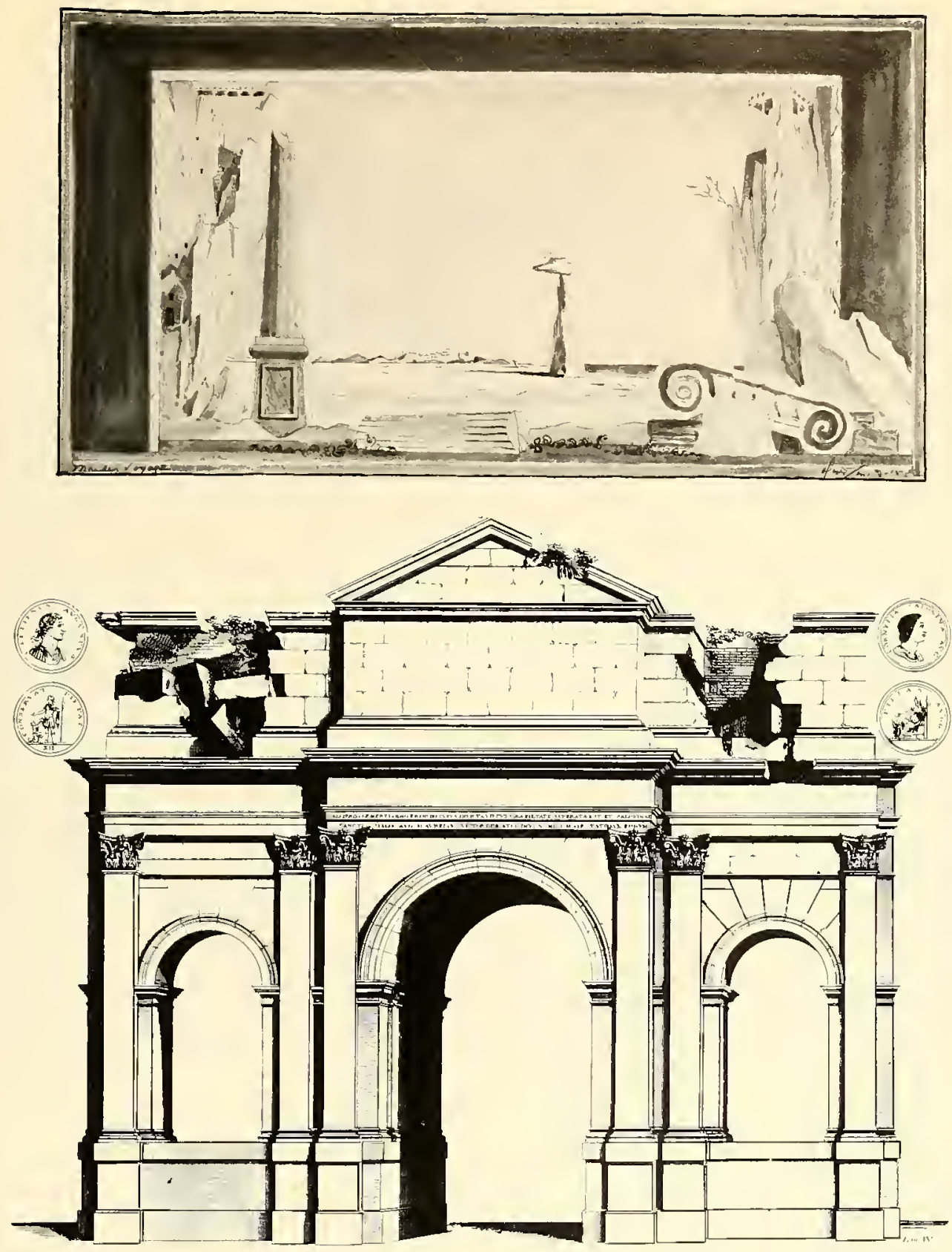


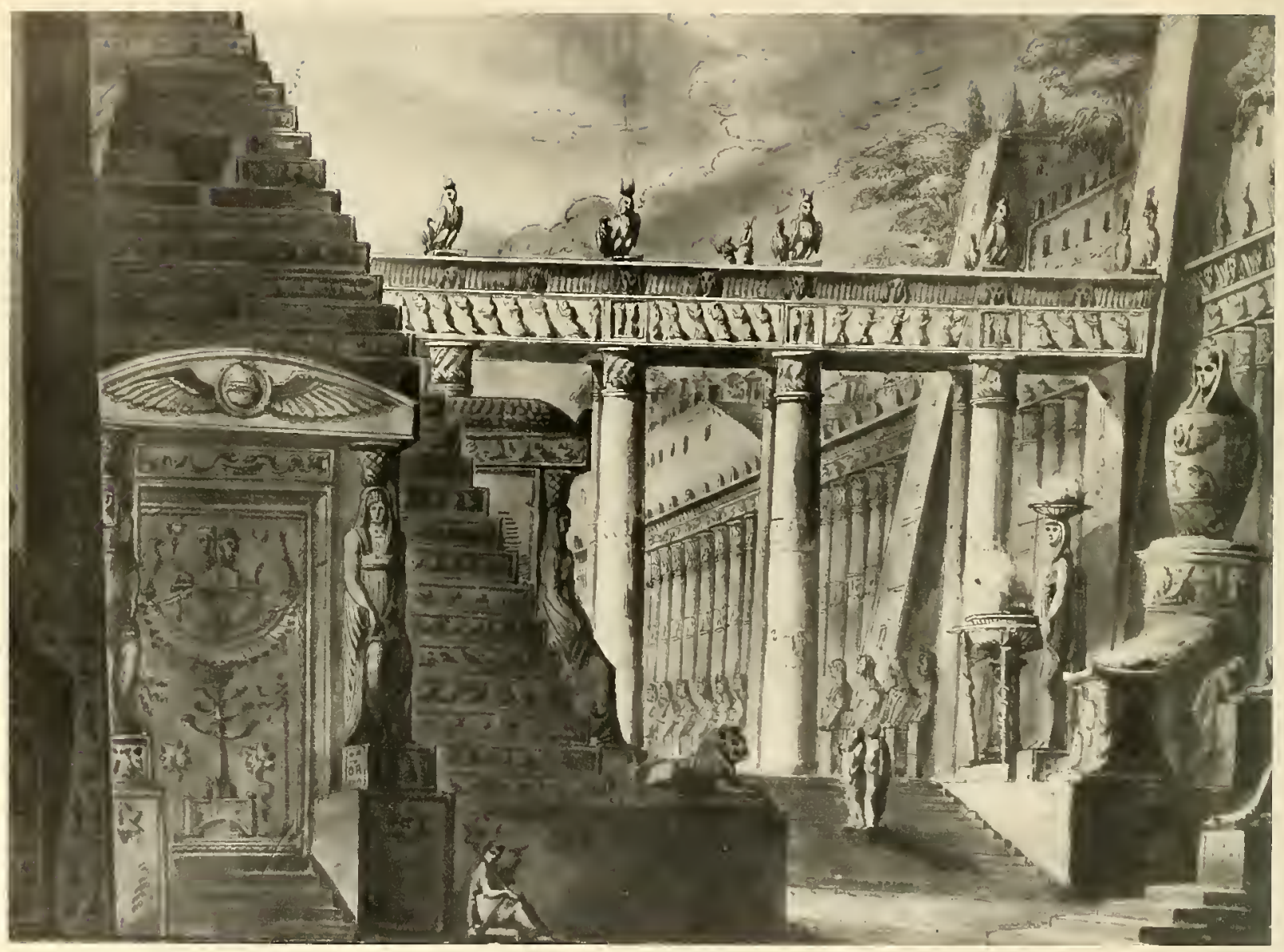

Antonio Basoli (1774-1848)

Italy

Stage Design: Egyptian Temple

Pen and black ink, gray to black wash

drawing

Purchase, Friends of the Museum Fund

1938.88.434

$$
100 \% 09
$$




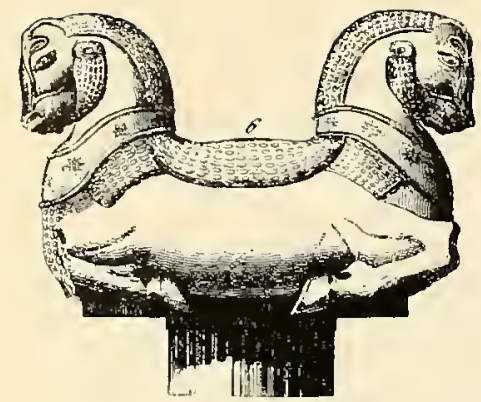

above:

Persepolis

Capital

Engraving

Cooper-Hewitt Museum Picture Library

right:

Giacomo Barozzi da Vignola

Livre Nouveau ou Regles des Cinq Ordres

d'Architecture, Paris, 1767

Plate 30: Manière de diminuer et torser les colomnes

Engraving

Cooper-Hewitt Museum Library

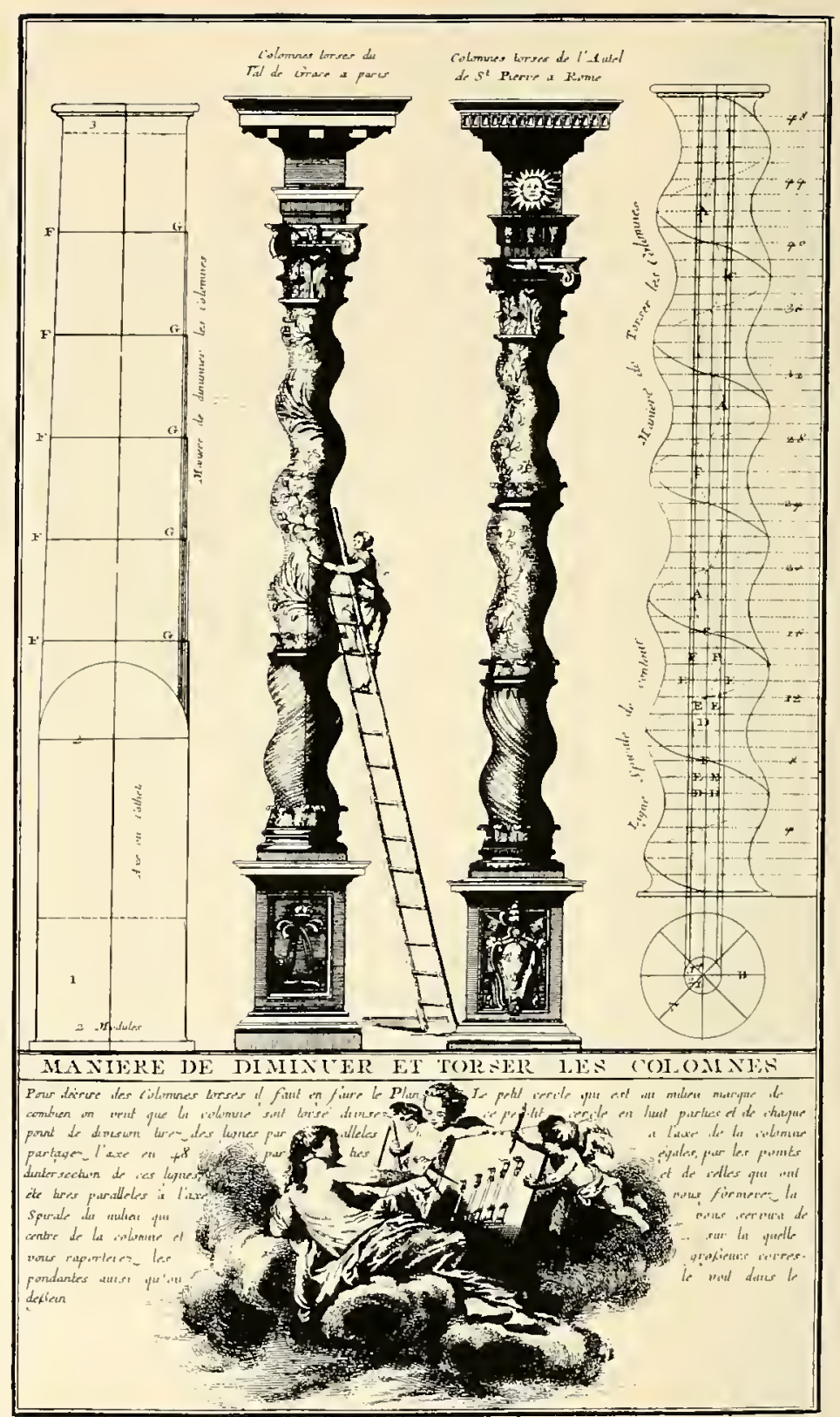


Giacomo Barozzi da Vignola Regola delli Cinque Ordini d'Architettura, 1563 Plate XX, Ionic Order Engraving

Gift of Henry O. Milliken

Cooper-Hewitt Museum Library

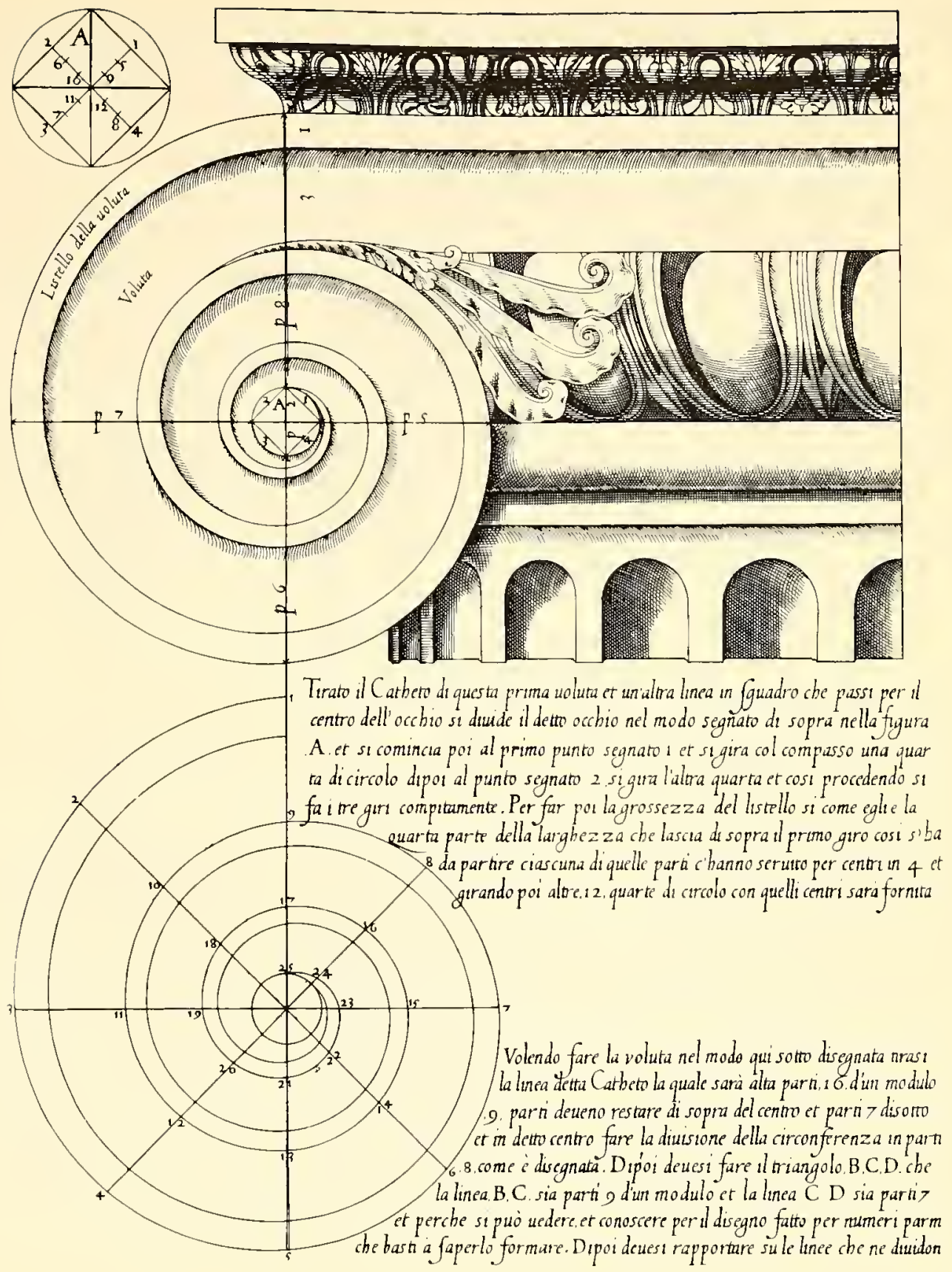



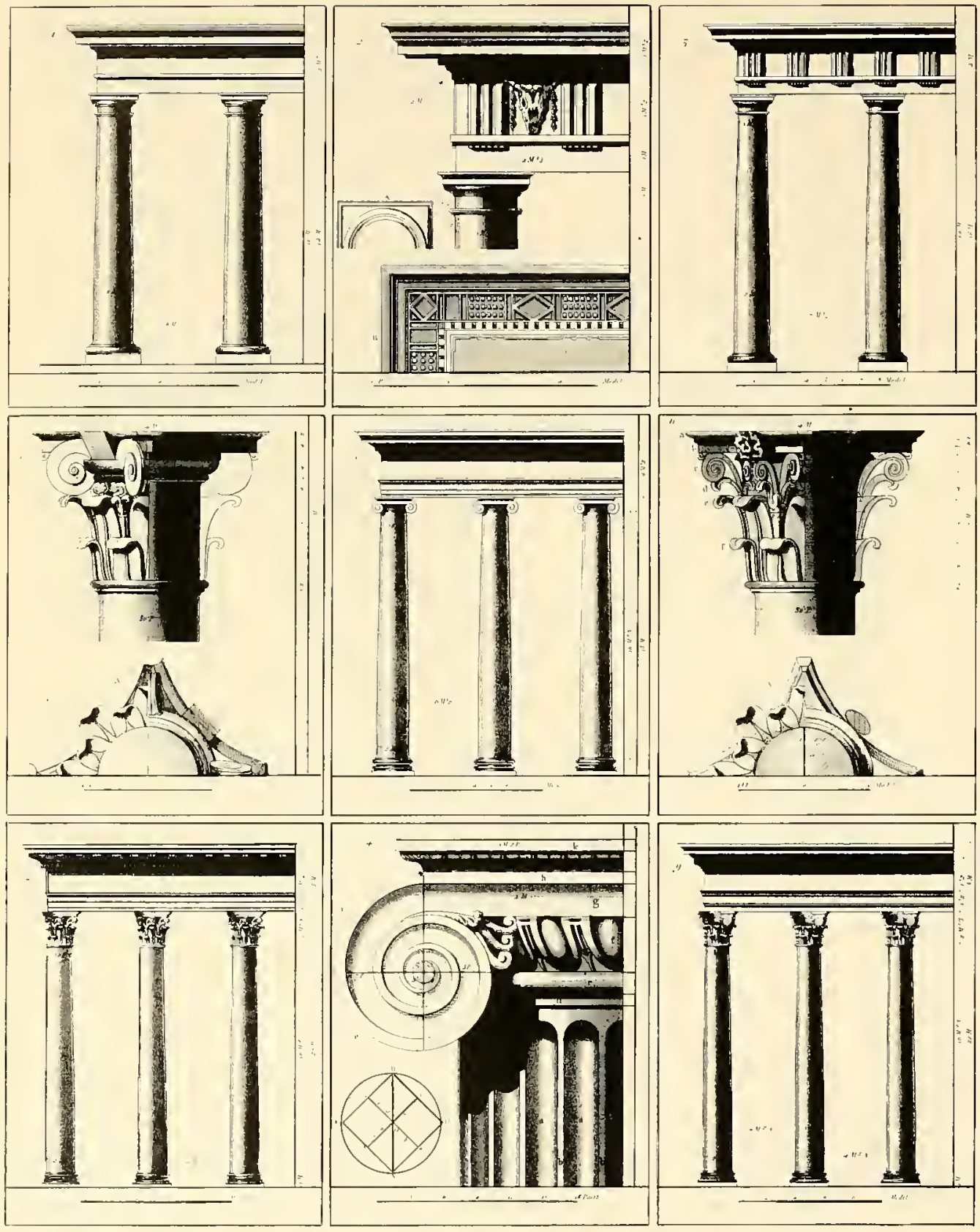

The Orders

Engraving

Cooper.Hewitt Museum

Picture Library 
Designed by Mentyka/Schlott Printed by Eastern Press, Inc. Typeset by Cardinal Type Service, Inc. 
Cooper-Hewitt Museum

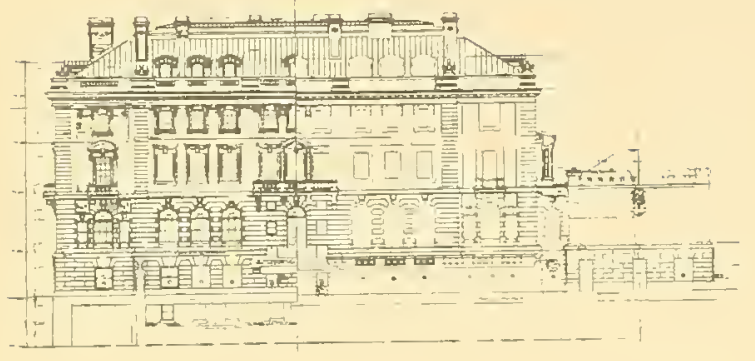

2 East 91st Street

New York, NY 10028 


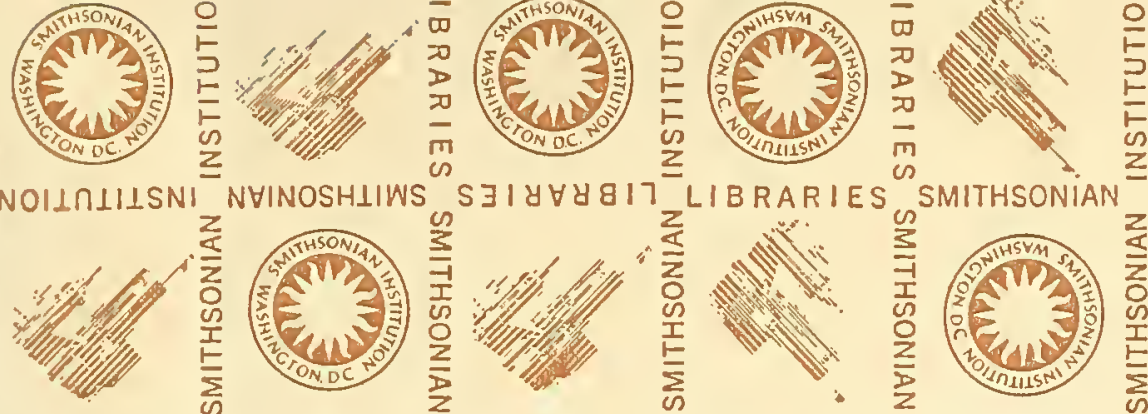

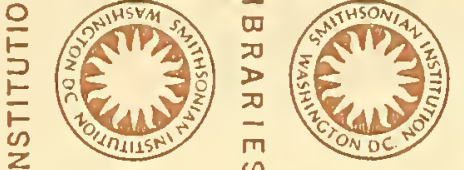

LIBRARIES SMITHSONIAN
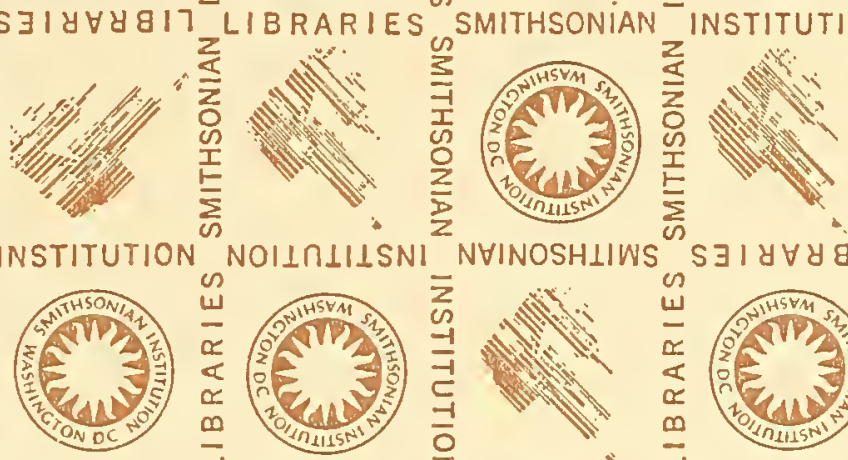

夏
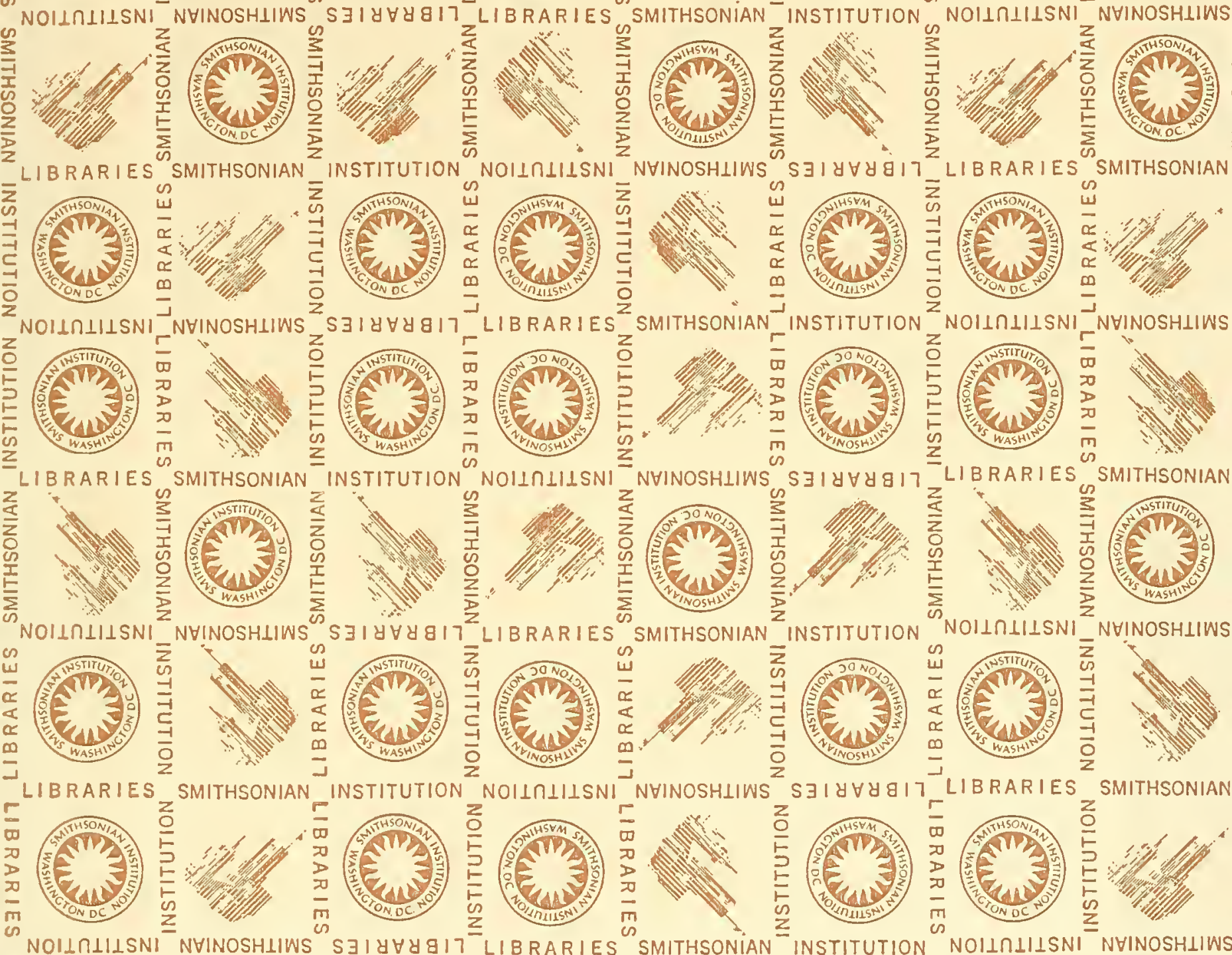

D

IBRARIES SMITHSONIAN

